\title{
Small extracellular vesicles secreted from human amniotic fluid mesenchymal stromal cells possess cardioprotective and promigratory potential
}

\author{
Kaloyan Takov ${ }^{1} \cdot$ Zhenhe He $^{1} \cdot$ Harvey E. Johnston ${ }^{2} \cdot J^{\prime}$ hn F. Timms ${ }^{2} \cdot$ Pascale V. Guillot $^{2} \cdot$ Derek M. Yellon $^{1}$. \\ Sean M. Davidson ${ }^{1}$
}

Received: 2 January 2020 / Accepted: 21 February 2020 / Published online: 7 March 2020

(c) The Author(s) 2020

\begin{abstract}
Mesenchymal stromal cells (MSCs) exhibit antiapoptotic and proangiogenic functions in models of myocardial infarction which may be mediated by secreted small extracellular vesicles (sEVs). However, MSCs have frequently been harvested from aged or diseased patients, while the isolated sEVs often contain high levels of impurities. Here, we studied the cardioprotective and proangiogenic activities of size-exclusion chromatography-purified sEVs secreted from human foetal amniotic fluid stem cells (SS-hAFSCs), possessing superior functional potential to that of adult MSCs. We demonstrated for the first time that highly pure (up to $1.7 \times 10^{10}$ particles/ $\mathrm{gg}$ protein) and thoroughly characterised SS-hAFSC sEVs protect rat hearts from ischaemia-reperfusion injury in vivo when administered intravenously prior to reperfusion $(38 \pm 9 \%$ infarct size reduction, $p<0.05)$. SS-hAFSC sEVs did not protect isolated primary cardiomyocytes in models of simulated ischaemia-reperfusion injury in vitro, indicative of indirect cardioprotective effects. SS-hAFSC sEVs were not proangiogenic in vitro, although they markedly stimulated endothelial cell migration. Additionally, sEVs were entirely responsible for the promigratory effects of the medium conditioned by SS-hAFSC. Mechanistically, sEV-induced chemotaxis involved phosphatidylinositol 3-kinase (PI3K) signalling, as its pharmacological inhibition in treated endothelial cells reduced migration by $54 \pm 7 \%(p<0.001)$. Together, these data indicate that SS-hAFSC sEVs have multifactorial beneficial effects in a myocardial infarction setting.
\end{abstract}

Keywords Exosomes · Foetal stem cells $\cdot$ Size-exclusion chromatography $\cdot$ Ischaemia-reperfusion injury $\cdot$ Angiogenesis $\cdot$ PI3K · Proteomics

\section{Introduction}

The term "extracellular vesicles" (EVs) encompasses various populations of lipid-bilayer, nanosized vesicles released into the extracellular space by all cell types [42]. With their diverse protein and RNA cargo, small EVs (sEVs, 30-150 $\mathrm{nm}$ in diameter; commonly referred to as

Electronic supplementary material The online version of this article (https://doi.org/10.1007/s00395-020-0785-3) contains supplementary material, which is available to authorized users.

Sean M. Davidson

s.davidson@ucl.ac.uk

1 The Hatter Cardiovascular Institute, University College London, 67 Chenies Mews, London WC1E 6HX, UK

2 EGA Institute for Women's Health, University College London, London, UK “exosomes" $[33,58])$ represent an exciting, potentially multitarget therapeutic for cardioprotection and heart repair $[16,17,20,52]$. sEV s can act as a means of communication between cells and may be responsible for a plethora of physiological or pathophysiological processes in the cardiovascular system [52].

Multipotent mesenchymal stromal/stem cells (MSCs) have been well documented to aid cardiac repair and longterm functional improvement of the heart following myocardial infarction [2]. These effects appear to be conferred by the MSC secretome [59], and are at least partially mediated by secreted sEVs [34, 52]. Multipotent MSCs can be isolated throughout development from a range of foetal as well as adult tissues [27, 28]. Compared to their adult counterparts, foetal MSCs possess greater expansion capacity [27] as well as better functional potential than adult MSCs [4, 48]. Amniotic fluid represents a rich source of foetal MSC, i.e., amniotic fluid stem cells (AFSCs), which can 
be harvested without significant ethical concerns during routine amniocenteses [27, 28, 62]. Both human AFSCs (hAFSCs) and hAFSC-conditioned medium alone were shown to decrease infarct size in a rat model of acute ischaemia-reperfusion injury [9], while hAFSCs are also more effective than adult bone marrow MSCs in promoting capillary formation in vivo [48]. The study of hAFSC EVs has only commenced recently, and their functional effects are not well understood $[4,6]$. Limited experimentation indicates that hAFSC sEVs may not be potently proangiogenic in their naïve state [5, 6]. On the other hand, Balbi et al. have recently demonstrated that hAFSC sEVs can reduce infarct size and improve cardiac function when injected intramyocardially in a model of permanent myocardial infarction in mice [5]. It remains unknown whether hAFSC sEVs deliver cardioprotective or proangiogenic benefits in a setting of myocardial ischaemia-reperfusion.

Amongst the different hAFSC subpopulations, spindleshaped fibroblast-like hAFSCs (SS-hAFSCs) represent only a small fraction of the hAFSCs, but exhibit considerably greater stemness and protective potential than other hAFSC subpopulations, as demonstrated in a model of brain ischaemia in mice [14]. Thus, SS-hAFSCs are an attractive and unexplored novel source of secreted factors, which may have potential clinical application in the treatment of myocardial infarction and its consequences.

A major debate in the sEV field concerns the purity of the obtained vesicle samples due to contamination of the samples with non-EV proteins, RNAs, and lipoproteins $[42,58]$. Furthermore, common and widely used isolation approaches, such as ultracentrifugation, may compromise $\mathrm{sEV}$ integrity leading to vesicle breakdown, aggregation, or fusion which can alter the functions of the sEVs [35]. On the other hand, size-exclusion chromatography (SEC) is a technique deemed to be superior to most other methods as it does not require high-speed centrifugation, lengthy procedures, or expensive equipment, and it preserves vesicular structure well $[8,37]$.

In this report, we isolated sEVs from SS-hAFSC-conditioned medium using a highly standardised protocol of ultrafiltration combined with SEC. We systematically characterised the purified vesicles and investigated their role in cardioprotection and angiogenesis. Our findings demonstrated that SS-hAFSC sEVs provide acute protection to the rat myocardium against ischaemia-reperfusion injury in vivo when administered via a clinically suitable intravenous route at the time of reperfusion. Intriguingly, sEVs did not protect isolated rat cardiomyocytes in vitro, indicative of indirect pro-survival effects. SS-hAFSC were not proangiogenic in vitro but promoted marked migration of endothelial cells which required phosphatidylinositol-3-kinases (PI3K) signalling. We have further shown that sEVs are an essential component of the SS-hAFSC-conditioned medium which loses its promigratory activity upon $\mathrm{sEV}$ depletion. These findings shed new light on the benefits provided by foetal MSC sEVs in cardioprotection and angiogenesis.

\section{Materials and methods}

Extended procedural details are provided in the Supplementary Methods.

\section{Cell culture}

Amniotic fluid (AF) was collected from healthy donors after written informed consent was obtained from all participants or their legal guardians, in compliance with the Declaration of Helsinki. The ethical approval was given by the Research Ethics Committees of Hammersmith \& Queen Charlotte's Hospitals (2001/6234) for frozen samples and from NRES Committee London, Bloomsbury (14/ LO/0863) for fresh samples, in compliance with UK national guidelines [Review of the Guidance on the Research Use of Fetuses and Fetal Material (1989) also known as Polkinghorne Guideline. London: Her Majesty's Stationery Office, 1989: Cm762)] for the collection of human foetal tissue for research.

SS-hAFSCs were isolated as described previously [14]. Briefly, amniotic fluid was spun at low speed to pellet the cells which were resuspended in complete medium, seeded, and incubated until the appearance of adherent fibroblastlike cells. Colonies with similar morphology (i.e., spindleshaped) were propagated and characterised for MSC markers. SS-AFSCs were maintained in monolayers in DMEM (ThermoFisher) supplemented with 25-mM glucose, 4-mM GlutaMAX, 50 units $/ \mathrm{ml}$ penicillin (Sigma), $50-\mu \mathrm{g} / \mathrm{ml}$ streptomycin (Sigma), and 9\% FBS (F9665, Sigma). SS-AFSCs from passages 11-20 were used for experiments.

Human umbilical vein endothelial cells (HUVECs) were obtained from Lonza as a pooled donor sample (C2519A) and maintained in monolayers in Endothelial Cell Basal Medium 2 (C-22211, PromoCell) supplemented with Endothelial Cell Growth Medium 2 SupplementPack (C-39211, PromoCell). HUVECs from passages 5-11 were used for experiments.

SS-hAFSCs and HUVECs were grown in a conventional tissue culture incubator at $37{ }^{\circ} \mathrm{C} / 5 \% \mathrm{CO}_{2}$ and detached with TrypLE Express Enzyme (ThermoFisher) for passaging. SS-hAFSCs images were taken using Nikon Eclipse TE200 inverted microscope (Nikon). 


\section{Flow cytometry}

SS-hAFSC were characterised by flow cytometry using the antibodies listed in Supplementary Table 1. See supplementary methods for further details.

SS-hAFSCs' death and apoptosis were estimated by Apoptosis Detection Kit I (556547, BD Biosciences) following the manufacturer's instructions.

\section{Isolation of SS-hAFSC small extracellular vesicles (sEVs)}

SS-hAFSC-conditioned medium was collected from $\sim 5-10 \times 10^{6}$ SS-AFSCs $(2 \times$ T225 flasks, $60 \mathrm{ml}$ culture medium in total) cultured in serum-free conditions for the indicated time periods. SS-AFSC sEVs for tube formation assay and in vivo experiments were isolated from $\sim 40-55 \times 10^{6}$ SS-AFSCs $(10 \times$ T22 2 flasks, $300 \mathrm{ml}$ culture medium in total). Conditioned medium was spun at $300 \mathrm{~g}$ for $10 \mathrm{~min}, 4^{\circ} \mathrm{C}$ to remove dead cells. Supernatant was then centrifuged at $10,000 \mathrm{~g}$ for $40 \mathrm{~min}, 4^{\circ} \mathrm{C}$ (polycarbonate tubes, 355,630, Beckman Coulter; MLA-55 rotor, Optima MAX-XP, Beckman Coulter) to remove cell debris and large vesicles. After discarding the pellet, conditioned medium was concentrated to $\sim 200-450 \mu$ using Vivaspin-15R ultrafiltration units (30 kDa, Hydrosart membrane, Sartorius). The remaining concentrate was immediately processed for SEC on qEVoriginal columns (iZON Science) [8]. Fractions were collected and pooled as indicated and stored at $-80^{\circ} \mathrm{C}$.

\section{Characterisation of SS-hAFSC small extracellular vesicles (sEVs)}

\section{Nanoparticle tracking analysis}

Nanoparticle tracking analysis (NTA) was performed following recommendations [26] adapted to the type of samples in our studies. NanoSight LM10-HS instrument (Malvern), 488-nm laser module, and NTA 3.1 software version were used for analysis. A syringe pump with constant flow injection was used and 3-5 videos of $30 \mathrm{~s}$ were captured with Camera Level of 15 and Detection Threshold of 4 .

\section{Protein assays}

Bicinchoninic acid (BCA) protein assay kit for low concentrations (ab207002, Abcam) and Bradford assays (in-house made using Coomassie Brilliant Blue G-250, 44,329, BDH) were used to quantify the protein content of SS-hAFSC-conditioned medium and SEV isolates. BCA assays were performed according to the manufacturer's instructions $(300-\mu \mathrm{l}$ final reaction volumes; 2-h incubation time). Higher protein content samples were analysed using standard BCA assay (Sigma) in 200- $\mu$ final reaction volumes for a 30-min incubation time. Absorbance for both assays was read at $562 \mathrm{~nm}$ on an FLUOstar plate reader (BMG Labtech) and protein concentrations were calculated using BSA standards and a four-parameter logistic curve.

Bradford assays were performed in $300-\mu l$ final reaction volumes, with 10-min incubation time and measurement of absorbance at $595 \mathrm{~nm}$ on an FLUOstar plate reader (BMG Labtech). Protein concentrations were calculated using BSA standards and a four-parameter logistic curve.

\section{Dot blot protein analysis}

$\sim 50$-ng protein of SS-hAFSC lysate, SS-hAFSC-conditioned medium, or isolated SS-hAFSC sEVs was lysed using $0.1 \%(\mathrm{v} / \mathrm{v}$ ) Triton X-100 (Sigma), vortexed, and pipetted on nitrocellulose membranes $(10,600,003$, GE Healthcare). After drying out, the membranes were blocked using a solution of 5\% BSA/0.1\% Tween-20 (Sigma) in PBS for $1 \mathrm{~h}$ at room temperature, and incubated with primary antibodies at $1 \mu \mathrm{g} / \mathrm{ml}$ in $5 \% \mathrm{BSA} / 0.1 \%$ Tween-20/PBS overnight at $4{ }^{\circ} \mathrm{C}$ (CD63: Clone H5C6, BD Biosciences; CD81: Clone JS-81, BD Biosciences; ACTN4: Clone C2C3, GeneTex). Secondary antibodies were added for $1 \mathrm{~h}$ at room temperature (1/10,000; goat anti-mouse IgG for CD63 and CD81, 926-32,210, LI-COR and goat anti-rabbit IgG for ACTN4, 926-32,211, LI-COR). Membranes were imaged using Odyssey system (LI-COR).

\section{Dissociation-enhanced lanthanide fluorescence immunoassay (DELFIA)}

Exosome-specific markers were quantified using a previously described dissociation-enhanced lanthanide fluorescence immunoassay (DELFIA) [55, 56, 64]. Samples were added to a high-binding 96-well microplate (DY990, R\&D Systems). After overnight incubation at $4{ }^{\circ} \mathrm{C}$, blocking with $1 \% \mathrm{BSA} / \mathrm{PBS}$ for $1 \mathrm{~h}$ at room temperature was performed. This was followed by primary antibody incubation at $1 \mu \mathrm{g} /$ $\mathrm{ml}$ in PBS for $2 \mathrm{~h}$ at room temperature (CD9: Clone M-L13, BD Biosciences; CD63: Clone H5C6, BD Biosciences; CD81: Clone JS-81, BD Biosciences) and secondary antibody incubation at $0.25 \mu \mathrm{g} / \mathrm{ml}$ in PBS for $1 \mathrm{~h}$ at room temperature (biotin-conjugated goat anti-mouse IgG1, ab98691, Abcam). 1:1000 Eu-labelled streptavidin in DELFIA Assay Buffer (PerkinElmer) was then added and incubated for $1 \mathrm{~h}$ at room temperature. Finally, 100- $\mu$ l DELFIA Enhancement Solution (PerkinElmer) was added to each well and timeresolved fluorimetry was performed using a PHERAstar 
plate reader (BMG Labtech) with excitation at $337 \mathrm{~nm}$, detection at $620 \mathrm{~nm}$, integration start at $60 \mu \mathrm{s}$, and integration time of $200 \mu \mathrm{s}$. Results are presented as arbitrary units (AU).

\section{Transmission electron microscopy (TEM)}

$\sim 2 \mu \mathrm{l}$ of each sample were adsorbed on Formvar-carbon electron microscopy grids. After washing with $\mathrm{H}_{2} \mathrm{O}$, the grids were transferred to a drop of $0.5 \%$ uranyl acetate solution [57], $\mathrm{pH} 7$ for $\sim 3 \mathrm{~min}$. Excess fluid was blotted, and the grids were imaged using a Jeol JEM-1010 electron microscope (Jeol Ltd).

\section{Protein arrays}

Protein profiling of SS-hAFSC sEVs was performed using Proteome Profiler Human Angiogenesis Array Kit and Cytokine Array Kit (ARY007 and ARY005B, respectively; R\&D Systems) following the manufacturer's instructions with some modifications. Each membrane was incubated with $\sim 15 \mu \mathrm{g}$ SS-hAFSC sEV protein for Cytokine Arrays and $\sim 10 \mu \mathrm{g}$ SS-hAFSC sEV protein for Angiogenesis Arrays. Prior to incubation, sEVs were lysed with addition of $0.1 \%$ (v/v) Triton X-100 and vortexing for $30 \mathrm{~s}$ [43]. Streptavidin-DyLight 800 conjugate was used for the detection of biotin-conjugated antibodies at $250 \mathrm{ng} / \mathrm{ml}(21,851$, ThermoFisher). Membranes were imaged, and densitometry was performed on Odyssey system. The spot coordinates can be found on https://resources.rndsystems.com/pdfs/datas heets/ary007.pdf and https://resources.rndsystems.com/pdfs/ datasheets/ary005b.pdf. Duplicate spot pixel densities were normalised to reference control spots and presented as relative pixel densities.

\section{Proteomics: liquid chromatography-tandem mass spectrometry (LC-MS/MS)}

SS-hAFSC-conditioned medium or isolated SS-hAFSC sEVs containing $\sim 30 \mu \mathrm{g}$ of protein were lysed using $0.5 \%$ $(\mathrm{w} / \mathrm{v})$ sodium dodecyl sulphate and vortexing, and concentrated to $\sim 50 \mu \mathrm{l}$ on Vivaspin-500 ultrafiltration units $(5-\mathrm{kDa}$ cut-off membranes, Sartorius). Samples were then reduced using $200 \mathrm{mM}$ tris(2-carboxyethyl)phosphine for $1 \mathrm{~h}$ at $60{ }^{\circ} \mathrm{C}$, alkylated with $200-\mathrm{mM}$ methyl methanethiosulfonate for $10 \mathrm{~min}$ at room temperature, and digested overnight with $1 \mu \mathrm{g}$ of proteomics grade trypsin (Promega). Detergent was removed using a detergent removal column (ThermoFisher), and peptides were isolated and fractionated by solid-phase extraction using $100 \mu \mathrm{l} \mathrm{C18} \mathrm{tips} \mathrm{eluting} \mathrm{into} \mathrm{5,} \mathrm{10,} \mathrm{15,} \mathrm{20,} \mathrm{25,}$
$30,35,40$, and $60 \%$ acetonitrile in $0.1 \%$ ammonium hydroxide. The peptide fractions were lyophilised and resuspended in $0.1 \%$ formic acid. $~ 500 \mathrm{ng}$ of each fraction was loaded by Dionex Ulitmate 3000 (ThermoFisher) onto a Pepmap100 C18 trapping cartridge $(5 \mathrm{~mm} \times 5 \mu \mathrm{M} \times 0.3 \mu \mathrm{m})$ and eluted over a reverse phase gradient [6\% (3 min), 35\% (35 min), 90\% (40 min) organic phase (95\% ACN, 5\% DMSO, 0.1\% FA) in aqueous phase (5\% DMSO, $0.1 \%$ FA)]. Peptides were resolved with a Pepmap C18 $(25 \mathrm{~cm} \times 3 \mu \mathrm{m} \times 100 \AA)$ at $300 \mathrm{nl} / \mathrm{min}$ and analysed with an LQT-Orbitrap XL mass spectrometer (ThermoFisher). MS analysis of eluting peptides was conducted between 400 and $1700 \mathrm{~m} / \mathrm{z}$ at 60,000 mass resolution. The top four precursor ions per MS scan were characterised by tandem MS with CID (ion trap MS, $2 \mathrm{Da}$ isolation window, $35 \mathrm{keV}$ ). The DMSO ion at 401.922718 was used as a lockmass. Target-decoy searching of raw spectral data was performed with Proteome Discoverer software version 1.4.1.14 (ThermoFisher). Spectra were searched using SequestHT (version 1.1.1.11) against the human and bovine UniProt Swissprot database (downloaded July 2019; supplemented with cRAP contaminations). Settings were: a fragment ion mass tolerance of $0.5 \mathrm{Da}$, a precursor mass tolerance of $10 \mathrm{ppm}$, searching for tryptic peptides allowing one missed cleavage, fixed modification of Methythio (C), variable modification of oxidation (M), and deamidation $(\mathrm{N}, \mathrm{Q})$ with percolator used to estimate FDR with a threshold of $q<0.01$.

Label-free quantitation (LFQ) enrichment ratios were calculated by LFQ of a 2-ppm precursor ion area and were normalised on total protein observation. The minimum LFQ peptide area value (defined as the smallest observed peptide quantitation) was $1.64 \mathrm{E}+04$. For minimum LFQ peptide area values, enrichment ratios are presented as " $\infty$ " or " $-\infty$ " indicating protein detection only in sEVs or conditioned medium, respectively.

Peptide-spectrum match (PSM) enrichment ratios were calculated by determining the relative number of PSMs observed for each protein after normalisation on total protein observation.

Functional enrichment analysis was performed using $\mathrm{g}$ :Profiler (version e96_eg43_p13_563554d, database updated on 05/06/2019) with g:SCS multiple testing correction method and a significance threshold of 0.05 [46]. Proteins detected in the sEV samples or proteins enriched in or exclusive to the sEV samples were used, excluding those assigned a minimum LFQ value and those with $<2$ PSMs. Fold enrichment analysis was performed which represents the occurrence of the proteins associated with the indicated terms relative to the expected occurrence based on the query 
size and the total human proteome size. Complete analysis can be found in the Supplementary Proteomics Table.

STRING database online tool version 11.0 [54] was used to produce a network of SS-hAFSC SEV-enriched and SShAFSC sEV-exclusive proteins (the highest confidence setting was chosen with interaction score of $\geq 0.900$ and disconnected nodes were hidden). sEV enrichment was defined as $>1.5$ times $\left(\log _{2}>0.58\right)$ higher LFQ peptide area in the sEV sample compared to the conditioned medium sample.

Full data of the identified proteins are presented in the Supplementary Proteomics Table. "CM" notation in the table refers to SS-hAFSC-conditioned medium, while "sEVs" notation refers to SEC-isolated SS-hAFSC sEVs. "sEV-enr $>1.5 \mathrm{x}$ " refers to proteins enriched in $\mathrm{sEVs}>1.5$ times or exclusive to sEVs by LFQ peptide area.

\section{EV-TRACK}

The relevant data were submitted to the EV-TRACK knowledgebase (EV-TRACK ID: EV190058) [22].

\section{Ethical approval for animal use}

All procedures were approved by the Animal Welfare and Ethical Review Body (AWERB) and were conducted within the terms of the United Kingdom Home Office Guide on the Operation of Animals (Scientific Procedures) Act 1986, the Directive 2010/63/EU of the European Parliament on the protection of animals used for scientific purposes and the NIH guidelines.

\section{In vivo non-recovery ischaemia-reperfusion injury model}

Rats were anaesthetized with $100-\mathrm{mg} / \mathrm{kg}$ pentobarbital injected intraperitoneally, and then subjected to in vivo myocardial ischaemia-reperfusion injury by ligation of left anterior descending (LAD) artery for $30 \mathrm{~min}$. Treatments [vehicle-PBS, bradykinin (positive control), SS-hAFSC sEVs] were administered intravenously via a jugular vein cannula 2 min prior to reperfusion. Following a 2-h reperfusion, experiments were terminated by excision of the heart, and myocardial infarct size was measured using tetrazolium staining $[10,36]$.

The in vivo experiments were randomised, and the operator was blinded to the administered treatment. The results are represented as the average of the analyses of two different experimenters who were blinded to treatment.

See supplementary methods for further details.

\section{Models of cardiomyocyte death in vitro}

Primary cardiomyocytes were isolated from the left ventricles of buffer-perfused adult rat hearts digested with collagenase and protease. Cells were seeded on laminin precoated 24-well plates.

A model of acute reactive oxygen species (ROS)-induced death of cardiomyocytes was established by 2 -h treatment of rat cardiomyocytes with hydrogen peroxide $\left(\mathrm{H}_{2} \mathrm{O}_{2}\right)$.

A model of hypoxia/reoxygenation of rat cardiomyocytes in vitro was set up to simulate ischaemia-reperfusion injury in vitro (simulated ischaemia-reperfusion injury). Cardiomyocytes were subjected to hypoxia for $5 \mathrm{~h}$ followed by a reoxygenation for $1 \mathrm{~h}$ in hypoxic and normoxic buffers (Supplementary Table 2), respectively, to mimic normal and ischaemic milieu found in the heart during myocardial infarction.

The protective effects of SS-hAFSC sEVs in these models were evaluated using lactate dehydrogenase (LDH) release assay as a surrogate measurement for cell death.

See supplementary methods for further details.

\section{Endothelial cell assays}

A modified Boyden's chamber [11] assay was performed to assess for promigratory functions of SS-hAFSC sEV isolates on HUVECs.

HUVEC proliferation over a 48-h period was studied by 3-(4,5-dimethylthiazol-2-yl)-2,5-diphenyltetrazolium bromide (MTT) assay [41].

HUVEC tube formation assay on a thin-layer extracellular matrix-mimicking gel [24] was conducted to investigate the proangiogenic effects of SS-hAFSC sEVs in vitro.

See supplementary methods for further details.

\section{Studies of signalling pathways in endothelial cells}

Activation of the PI3K signalling pathway (AKT and PRAS40) in HUVECs by SS-hAFSC sEVs was studied by western blotting (see Supplementary Table 3 for antibody details).

Phosphorylation of intracellular signalling kinase pathways was investigated using Proteome Profiler Human Phospho-Kinase Array Kit (ARY003B, R\&D Systems).

See supplementary methods for further details.

\section{Statistical analysis}

Data are plotted as means \pm SEM. GraphPad Prism was used for statistical analyses and graph production (GraphPad Software). Statistical comparisons were performed 
using Student's $t$ tests, one-way ANOVA with Tukey's or Dunnett's post hoc tests or two-way ANOVA as indicated. $p$ values of less than 0.05 were considered significant.

\section{Results}

\section{Characterisation of SS-hAFSCs}

Human SS-hAFSCs have previously been thoroughly characterised for their tri-lineage differentiation potential [40].
A

FBS vs No FBS, $24 \mathrm{~h}$


FBS vs No FBS, $48 \mathrm{~h}$
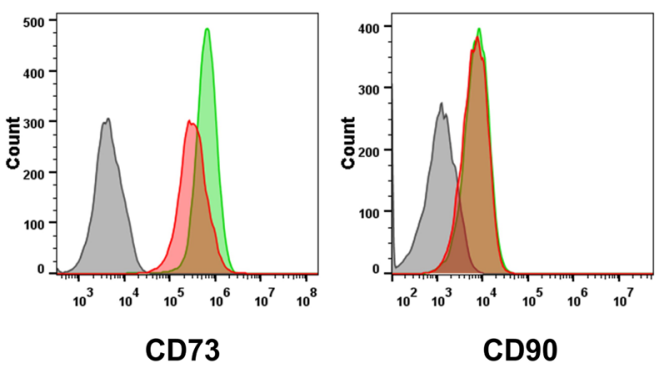

CD90



CD105

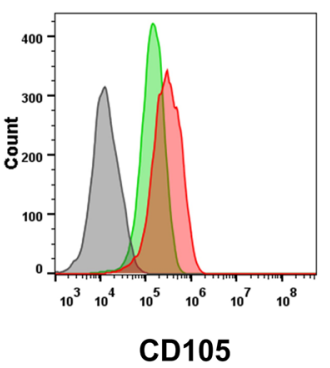

CD105
B

FBS vs No FBS, $24 \mathrm{~h}$
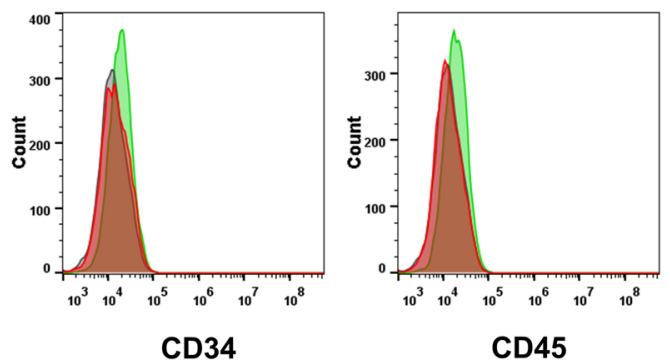

FBS vs No FBS, $48 \mathrm{~h}$
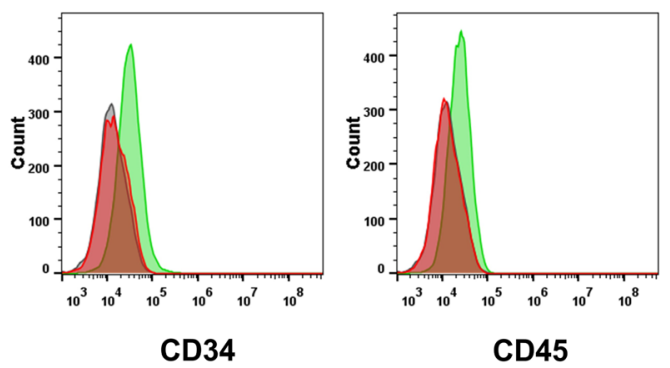

FBS

No FBS

Unlabelled FBS
C

Cell number



D

Fig. 1 Characterisation of SS-hAFSCs after different incubation timings with or without serum. SS-hAFSCs were incubated for $24 \mathrm{~h}$ or $48 \mathrm{~h}$ in serum-supplemented or serum-free medium. a, b Membrane markers present on (a) or absent of (b) SS-hAFSCs after incubation in serum (FBS)-supplemented and serum-free (No FBS) condi-
Cell viability

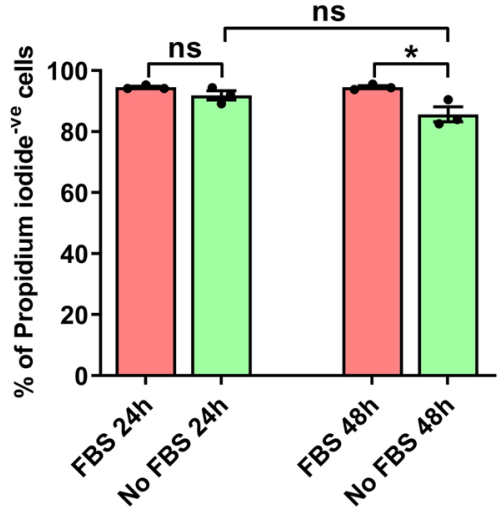

tions. c Cell number after each incubation timing normalised to day 1. $n=3$. d Live cells (propidium iodide (PI)-negative) after different incubation timings and conditions. $n=3 .{ }^{*} p<0.05, n s$ non-significant $(p>0.05)$, one-way repeated-measures ANOVA with Tukey's post hoc test 
SS-hAFSCs expressed cell surface markers CD73 (99.3\%), CD90 (65.3\%), CD105 (99.5\%), CD29 (99.1\%), and CD44 (100.0\%), and were negative for CD14, CD34, and CD45, satisfying the criteria for MSC identification [23] (Supplementary Fig. 1).

Serum-free culture significantly reduces subsequent protein and lipoprotein contamination of the sEV isolates [56]. To confirm that SS-hAFSC retained expression of MSC markers and viability during serum-free culture, cells were incubated for $24 \mathrm{~h}$ or $48 \mathrm{~h}$ in serum-free medium and MSC marker expression and cell death was evaluated. SS-hAFSCs retained expression of the MSC markers in serum-free conditions with a slight reduction in CD105 expression (Fig. 1a, b) and a mild cell elongation (Supplementary Fig. 2a), both reported previously for MSCs [38]. Despite a cessation of proliferation, cell numbers were maintained even after $48 \mathrm{~h}$ of serum-free incubation (Fig. 1c). Flow cytometry showed cell survival of $>85 \%$ (Fig. 1d) of which $\sim 15 \%$ were undergoing early apoptosis (Supplementary Fig. 2b, c). These values were very similar to the previously obtained ones for cell viability of hAFSCs in a serum-free environment [6]. Importantly, despite a slight increase in cell death after a 48-h serum-free compared to serum-supplemented culture, there was no difference in viability between 24 and $48 \mathrm{~h}$ serum-free incubation (Fig. 1d and Supplementary Fig. 2b, c).

Overall, $24 \mathrm{~h}$ or $48 \mathrm{~h}$ serum-free incubation had only subtle effects on SS-hAFSCs' viability and expression of MSC markers, with negligible changes between 24 and 48 h of serum-free culture.

\section{Isolation and characterisation of SS-hAFSCs sEVs}

To isolate SS-hAFSC sEVs, ultrafiltration combined with SEC of serum-free conditioned medium was performed after $24 \mathrm{~h}$ or $48 \mathrm{~h}$ of incubation. SEC easily resolved particles (peak elution at 4.0-4.5 ml) from soluble-protein contaminants (peak elution at $10.5 \mathrm{ml}$ ) (Fig. 2a). DELFIA confirmed the presence of exosome marker proteins, the tetraspanins CD9, CD63, and CD81, in early SEC fractions with a peak at $4.5 \mathrm{ml}$ (Fig. 2b, c), which coincided with an early protein peak (Fig. 2d). The early SEC fractions contained more particles, protein, and exosome marker levels after $48 \mathrm{~h}$ compared to $24 \mathrm{~h}$ incubation (Fig. $2 \mathrm{a}-\mathrm{d}$ ). Furthermore, sEV purity was greater after $48 \mathrm{~h}$ than $24 \mathrm{~h}$ culture, as determined by the ratio of $\mathrm{CD} 9, \mathrm{CD} 63$, or CD81 markers to protein (Fig. 2e-g), and by the ratio of particle-to-protein content (a marker of EV purity [19, 63]) (Fig. 2h).

Pooled sEV-rich SEC fractions had $\sim 99.5 \%$ of the soluble protein removed and their ratio of particle-to-protein content reached $1.7 \pm 0.2 \times 10^{10}$ particles $/ \mu$ g protein, indicative of a very high purity (Fig. 3a). The majority of SS-hAFSC sEVs exhibited sizes typical for exosomes (30-150 nm) [33, 42], with some medium-sized EVs (Fig. 3b), and they expressed characteristic tetraspanin exosome markers (Fig. 3c). Additionally, there was a dramatic enrichment of CD63 and CD81 in the SS-hAFSC sEV samples compared to conditioned medium, and absence of alpha-actinin-4 (ACTN4), a characteristic protein of medium and large EVs [33], in the isolated sEVs (Fig. 3d). Transmission electron microscopy confirmed the presence of sEVs with characteristic concave disc shapes [52] in the isolates (Fig. 3e) and the absence of impurities which were clearly visible as aggregated dense material in the starting conditioned medium (Fig. 3e). Using LC-MS/MS, SS-hAFSC sEVs were found to be enriched in multiple EV markers [33] including: CD9, CD63, CD81, syntenin-1, TSG101, ALIX, ADAM10, flotillins, annexins, CD47, CD90, NT5E, and CAV1. Furthermore, they were depleted or devoid of non-sEV markers [33] including: HSP90B1, HSPA5, GOLGA2, LMNA, KRT18, and ACTN4. SS-hAFSC sEVs were also highly enriched in proteins associated with the Gene Ontology Cellular Component terms related to extracellular vesicles and exosomes $\left(p<1 \times 10^{-150}\right.$, Fig. 3f, Supplementary Proteomics Table). Notably, bovine apolipoproteins were not detected, implying the absence of carryover of lipoprotein particles to the isolated EVs.

Overall, $48 \mathrm{~h}$ serum-free incubation of SS-hAFSCs provided increased yield and purity of the obtained vesicles. To minimise soluble-protein contamination for our functional experiments, we used pooled sEV-rich fractions $4.0 \mathrm{ml}$, $4.5 \mathrm{ml}$, and $5.0 \mathrm{ml}$ after $48 \mathrm{~h}$ incubation in serum-free medium, hereafter labelled as "SS-hAFSC sEVs".

\section{SS-hAFSC sEVs are cardioprotective in vivo, but do not protect isolated cardiomyocytes in vitro}

To test the hypothesis that SS-hAFSC sEVs can protect the myocardium in vivo, we used a rat model of 30-min myocardial ischaemia followed by 2 -h reperfusion with intravenous treatment administration 2 min prior to reperfusion. As expected, a positive control (bradykinin) reduced infarct size (Fig. 4a). SS-hAFSC sEVs were also found to be cardioprotective, decreasing infarct size by $27 \%$, from $71 \pm 5 \%$ to $44 \pm 7 \%$ (Fig. $4 \mathrm{a}, \mathrm{c}$ ). The ischaemic area (i.e., area at risk) was not different between the groups (Fig. 4b, c).

Therefore, to investigate the potential cardioprotective mechanism of the SS-hAFSC sEVs, we used a model of reactive oxygen species (ROS)-induced death of primary adult rat ventricular cardiomyocytes. Initial experiments established a model, showing that $\mathrm{H}_{2} \mathrm{O}_{2}$ induces cardiomyocyte death with an $\mathrm{EC}_{50}$ of $41 \pm 4 \mu \mathrm{M}$ (Supplementary Fig. $4 \mathrm{a}$ ) and $N$-acetyl-L-cysteine (NAC) can efficiently 
A

SEC fractionation: particles \& protein

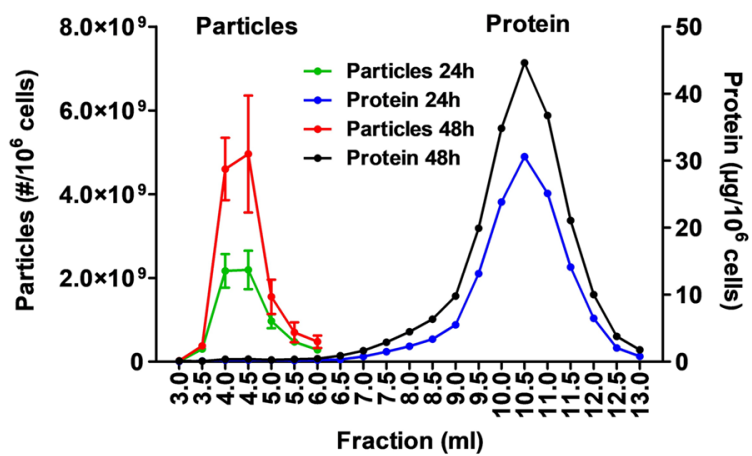

B Tetraspanin sEV markers: $24 \mathrm{~h}$

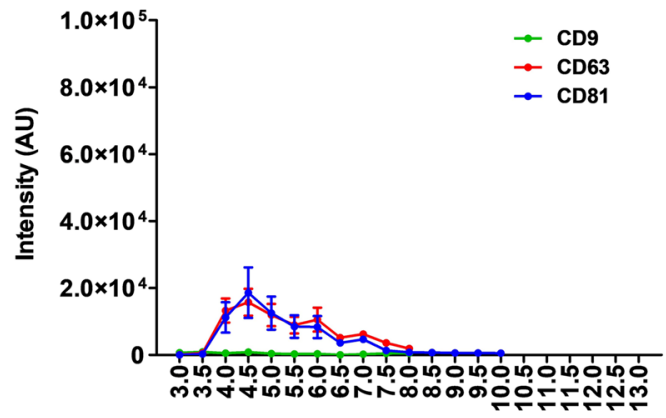

Fraction (ml)

C Tetraspanin sEV markers: $48 \mathrm{~h}$

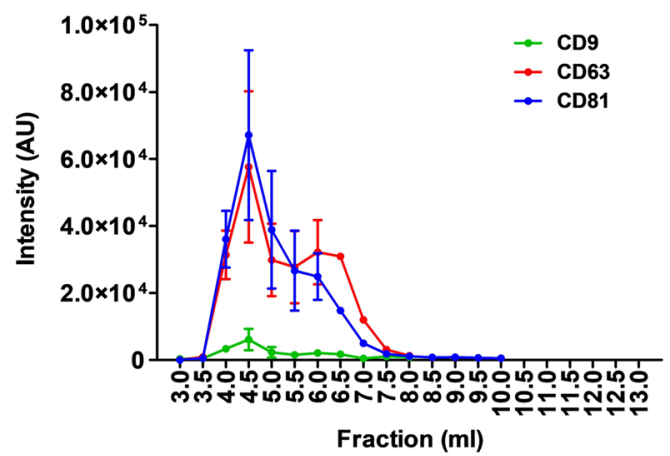

D

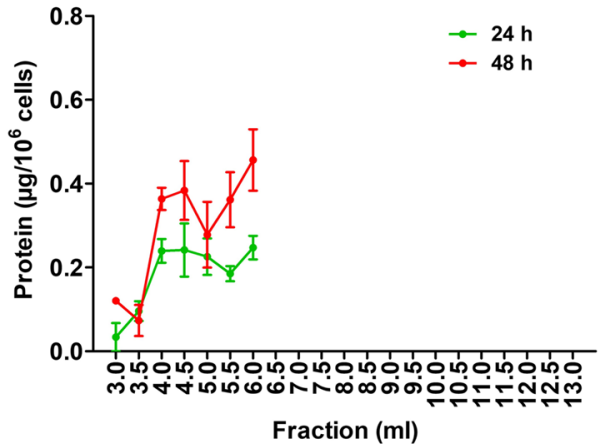

E

CD9 per $\mu \mathrm{g}$ protein

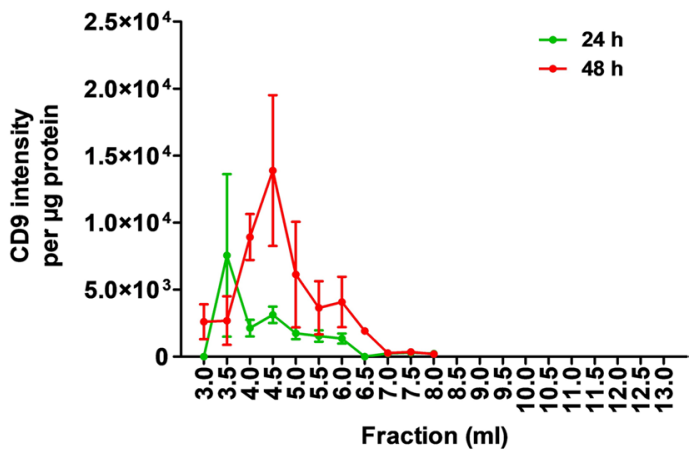

$\mathbf{F}$

\section{CD63 per $\mu \mathrm{g}$ protein}

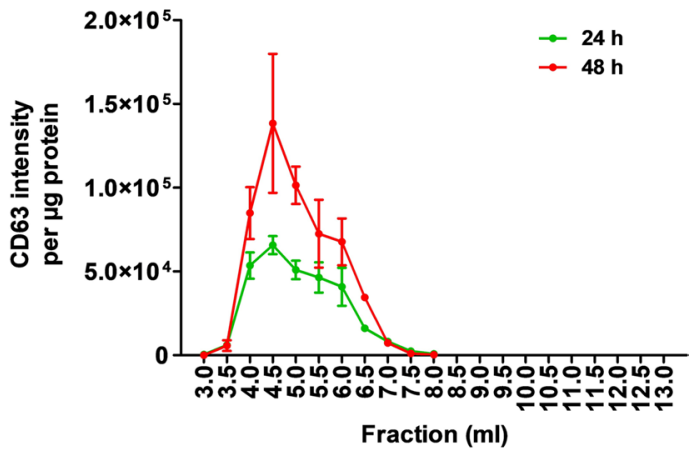

G

CD81 per $\mu$ g protein

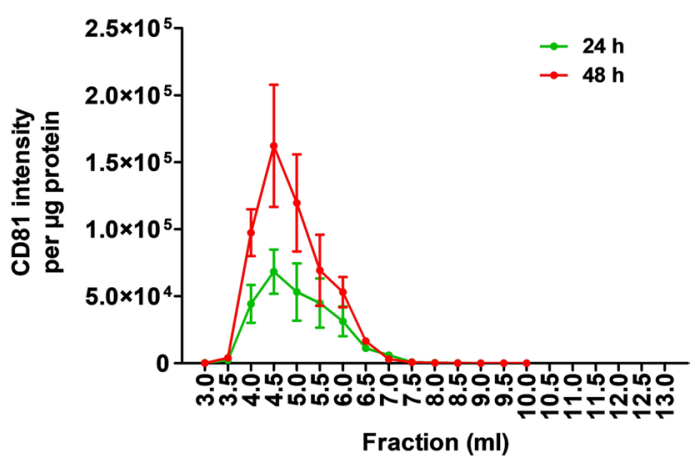

H Particle/protein ratio




4Fig. 2 Characterisation of SS-hAFSC sEVs after different incubation timings. sEVs were isolated by SEC of serum-free medium conditioned by SS-AFSCs for $24 \mathrm{~h}$ or $48 \mathrm{~h}$. a Particle and protein levels of SEC fractions measured by NTA and BCA assays, respectively. $p<0.01$ for Particles $24 \mathrm{~h}$ vs Particles $48 \mathrm{~h}$. b, c Exosome-specific tetraspanin markers of SEC fractions obtained from $24 \mathrm{~h}$ (b) or $48 \mathrm{~h} \mathrm{(c)} \mathrm{incubation} \mathrm{of} \mathrm{SS-AFSCs} \mathrm{measured} \mathrm{by} \mathrm{DELFIA.} p<0.01$ for CD9; $p<0.001$ for CD63 and CD81. d Protein amount of early SEC fractions. Note the low protein quantities and the early protein peak. $p<0.001$. e, g CD9 (e), CD63 (f), and CD81 (g) signal of SEC fractions normalised to protein amount. $p<0.05$ for $\mathbf{e} ; p<0.01$ for $\mathbf{g} ; p<0.001$ for $\mathbf{f}$. $\mathbf{h}$ Particle/protein ratio of early SEC fractions. $p<0.05 . n=3$ where error bars are present and $n=1$ where absent. Curves compared by two-way repeated-measures ANOVA (points with $n=3$ included)

protect against $\mathrm{H}_{2} \mathrm{O}_{2}$-induced death with the most consistent response conferred by $300 \mu \mathrm{M}$ NAC (Supplementary Fig. 4b, c). However, no protective effect of SS-hAFSC sEVs was seen in this assay (Fig. 4d, e).

Next, to investigate the cardioprotective mechanism in a more physiological model, we subjected cardiomyocytes to hypoxia/reoxygenation in vitro. Hypoxia/reoxygenation significantly increased cell death in comparison to the control normoxic conditions, but none of the doses of SS-hAFSC sEVs had protective effects in this model (Fig. 4f, g). This led us to hypothesize that the cardioprotection seen in vivo may be via an indirect mechanism via signalling from the endothelium. To test this, conditioned medium from HUVECs treated in vitro with SS-hAFSC sEVs or vehicle was collected, concentrated, and used to treat primary cardiomyocytes prior to hypoxia/reoxygenation. Similar to our previous observations, administration of SS-hAFSC sEVs alone did not protect cardiomyocytes. Furthermore, no protection was seen with conditioned medium from sEV-treated HUVECs (Fig. 4h), indicating that the stable secretome of sEV-treated endothelial cells does not mediate the cardioprotective effects of SS-hAFSC sEVs.

\section{SS-hAFSC sEVs promote migration of endothelial cells, but are not proangiogenic in vitro}

To assess the angiogenic potential of the isolated SS-hAFSC sEVs, HUVEC migration, proliferation, and tube formation in response to $\mathrm{SEV}$ s were studied.

SS-hAFSC sEVs promoted migration of endothelial cells in a dose-dependent manner with concentrations $\geq 3 \times 10^{9}$ particles/ml being effective (Fig. $5 \mathrm{a}$ ). sEV promigratory potential was marked and reached levels similar to the serum positive control used (Fig. 5a). Intriguingly, SShAFSC sEVs promoted endothelial cell proliferation, but these effects were subtle compared to the baseline proliferation levels and the serum control (Fig. 5b). Additionally, none of the doses of SS-hAFSC sEVs stimulated tube formation of endothelial cells in vitro (Fig. 5c, d).

Overall, SS-hAFSC sEVs had minor effects on proliferation and tube formation of endothelial cells, but potently stimulated endothelial cell migration in vitro.

\section{SS-hAFSC sEVs carry promigratory factors}

To obtain a profile of potential promigratory and proangiogenic factors present in the SS-hAFSC sEVs that may be responsible for the observed promigratory effects, two different strategies were used: protein arrays and proteomic analysis.

Using angiogenesis and cytokine protein arrays, multiple potential proangiogenic factors were found to be present in the conditioned medium and the sEV isolates (Fig. 6a, b). Some factors, such as PTX3, were clearly enriched in the isolated SS-hAFSC sEV samples, while others, such as PAI1, TIMP1, and TSP1, were mostly found in the conditioned medium (Fig. 6a, b). When examining protein expression using a cytokine array, many of the cytokines were identified, although none were present at particularly high levels in the sEVs. The most abundant ones in the sEVs were MIF and SDF1 (Fig. 6b).

Proteomic analysis confirmed most of the observations from the protein arrays (Supplementary Proteomics Table). This approach identified further potential promigratory mediators in the SS-hAFSC sEV samples such as BGN [29] and RTN4 [1] which were enriched in the sEV samples compared to the starting conditioned medium.

Next, we focussed on the sEV-exclusive and sEVenriched ( $>1.5$ times) proteins. Gene Ontology classification according to Biological Process yielded numerous terms overrepresented in the sEV proteome including those associated with cell migration (Fig. 6c). Interestingly, proteins associated with the term "positive regulation of locomotion" did not cluster together on a protein network (Supplementary Fig. 5 and Supplementary Proteomics Table), indirectly suggesting that the sEVs may stimulate migration via multiple independent mechanisms.

A recent study systematically compared the angiogenic potential of the secretome from several types of human MSCs including foetal Wharton's jelly MSCs, and found that biological processes related to angiogenesis were enriched in the secretomes of all MSC types, with the most complete angiogenic profile detected in the foetal MSC secretome [30]. Our proteomic analysis identified 106 additional, unique proteins in the SS-AFSC sEVs that were not detected in any of the adult or foetal MSC secretomes in this study (Supplementary Proteomics Comparison table). Interestingly, gene ontology analysis of these 106 proteins showed 
A Particle/protein ratio

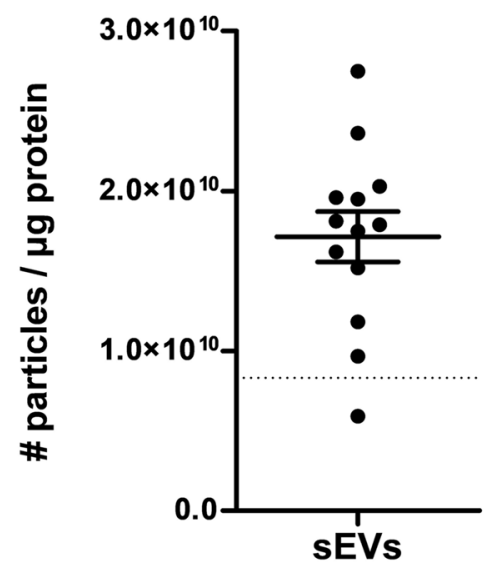

C

Tetraspanin content: sEV isolates

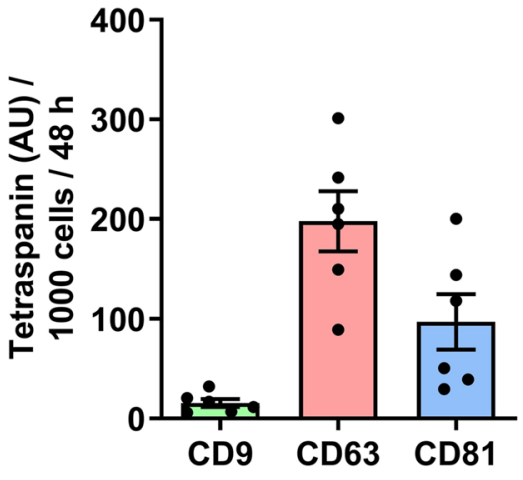

B

Particle size distribution: AFSC sEVs



D



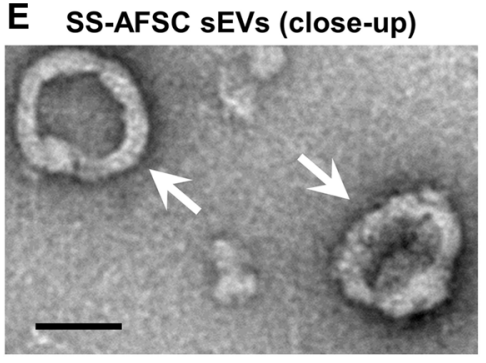



SS-AFSC-cond medium (close-up)


F

Fold enrichment

extracellular exosome extracellular vesicle extracellular organelle vesicle extracellular region part $1.0 \times 10^{-149}$
5.9

5.8

5.8

3.7

3.8 
4 Fig. 3 Characterisation of pooled SS-hAFSC sEVs. sEVs were isolated by SEC of serum-free medium conditioned by SS-hAFSCs for $48 \mathrm{~h}$ and sEV-rich fractions were pooled and analysed. a Particle/protein ratio. $n=13$. Dotted line-theoretical ratio of $8.3 \times 10^{9}$ particles/ $\mu \mathrm{g}$ protein reported for a pure population of sEVs [19]. b Particle-size distribution of SS-hAFSC sEVs. $n=25$. Red lines represent SEM. c Levels of tetraspanin exosome-specific markers CD9, CD63, and CD81. $n=6$. d Dot blots for CD63 and CD81 and ACTN4 (alphaactinin-4-medium/large EV-specific marker). e TEM images of SShAFSC sEVs and SS-hAFSC-conditioned medium. Arrows point to sEVs. Scales: top left-100 nm; top right $-500 \mathrm{~nm}$; bottom left$200 \mathrm{~nm}$; bottom right $-1 \mu \mathrm{m}$. F: Functional enrichment analysis of the proteins in SS-hAFSC sEVs. The top 5 gene ontology (GO) cellular component terms are shown

that the unique proteins from SS-AFSC sEVs associate with terms related to angiogenesis and (cardio) vascular development (Supplementary Proteomics Comparison table). Therefore, it will be interesting to compare the proangiogenic capacity of SS-AFSC with other types of MSCs in future studies.

Overall, SS-hAFSC sEVs carried diverse proteins, some of which are likely to be associated with the promigratory effects observed here. Intriguingly, some of the most abundant proteins, including SDF1 [13], MIF [31], PTX3 [32], RTN4 [1], and BGN [29], have previously been shown to exhibit chemotactic activities outside of EVs.

\section{SS-hAFSC sEVs are the active promigratory components of SS-hAFSC-conditioned medium}

Similar to the isolated SS-hAFSC sEVs, SS-hAFSC-conditioned medium demonstrated dose-dependent promigratory effects on endothelial cells (Fig. 7a). Intriguingly, the promigratory effects of the conditioned medium were completely lost when it was depleted of sEVs using our isolation protocol, indicating that the vesicles are the active chemotactic mediator of the SS-hAFSC secretome (Fig. 7b). It is possible, however, that this experiment was confounded by the multiple ultracentrifugation and ultrafiltration steps involved. Therefore, in a further experiment, we directly compared the sEV-rich fractions $(3.5 \mathrm{ml}-7.0 \mathrm{ml})$ to $\mathrm{sEV}$ poor (i.e., soluble protein-rich) fractions $(7.0 \mathrm{ml}-15.0 \mathrm{ml})$ of the SS-hAFSC-conditioned medium, omitting the ultrafiltration step. This experiment confirmed that the solubleprotein fraction of the conditioned medium has no significant promigratory effect, in comparison to the sEV fraction, which completely recapitulated the effects of the conditioned medium (Fig. 7c).

To investigate the mechanism of sEV-induced endothelial cell migration, we used pathway inhibitors of some abundant, candidate factors identified by protein arrays or proteomic analysis. Application of a neutralising anti-PTX3 antibody had no effect on sEV-induced migration (Fig. 7d). A CXCR4 inhibitor efficiently blocked migration in response to recombinant SDF1 $\alpha$ (Fig. 7e), but did not significantly reduce sEV-induced endothelial chemotaxis (Fig. 7f). Similarly, an inhibitor of TLR4 had no effect on endothelial cell migration stimulated by SS-hAFSC sEVs (Fig. 7g). Finally, application of a neutralising antibody against RTN4B also had no effect on the sEV-induced endothelial cell chemotaxis (Fig. 7h).

In summary, despite the complexity of the soluble-protein secretome of SS-hAFSCs, sEVs were found to be the active promigratory factor of the SS-hAFSC-conditioned medium. Furthermore, some of the abundant factors present in the sEVs (PTX3, SDF1, MIF, BGN, and RTN4B) were excluded as potential mediators of the promigratory effects.

\section{SS-hAFSC sEV-induced migration requires $\mathrm{PI} 3 \mathrm{~K}$ signalling}

Mechanistically, the PI3K pathway is a known player in endothelial cell migration [51]. Additionally, KEGG pathway analysis showed a significant overrepresentation of proteins associated with the PI3K-AKT signalling pathway in SS-hAFSC sEVs (Fig. 8a and Supplementary Proteomics Table). Intriguingly, inhibiting the PI3K pathway in endothelial cells reduced $\mathrm{sEV}$-stimulated migration by $54 \pm 15 \%$ (Fig. 8b). However, administration of sEVs led to only a subtle, non-significant increase in phosphorylation of AKT, a downstream PI3K target (Fig. 8c). We observed the same non-significant increase when using higher SEV concentration $\left(1 \times 10^{10}\right.$ particles $\left./ \mathrm{ml}\right)$ or additional downstream PI3K targets (i.e., PRAS40) (Supplementary Fig. 5a, b). Furthermore, a phospho-kinase array showed no increase in phosphorylation of 43 different signalling kinases or kinase targets in the endothelial cells for both short-term (i.e., $15 \mathrm{~min}$; Fig. 8d) or long-term (i.e. 3 h; Supplementary Fig. 5c) incubation with sEVs.

In summary, SS-hAFSC sEV-promoted endothelial cell migration required, but was not solely dependent on, PI3K signalling in the target endothelial cells.

\section{Discussion}

In this study, we used SEC to isolate highly pure, foetal MSC sEVs from medium conditioned by SS-hAFSCs. Our study provides the most extensive characterisation of the harvested 
A Infarct size

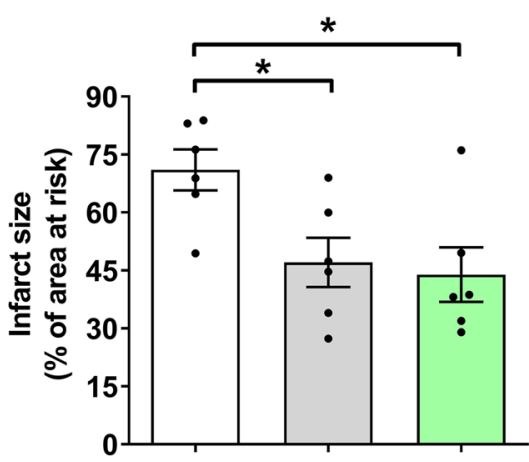

Venicle
$B$ radykinin
$S S-A F S C S E V S$
B Area at risk

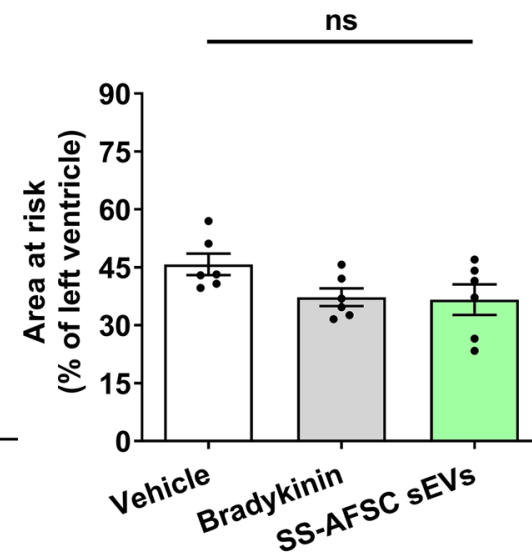

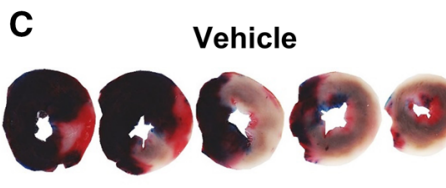

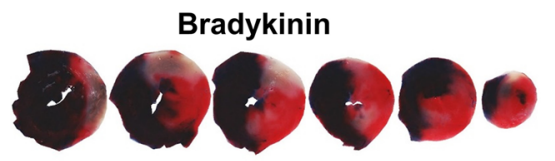

SS-AFSC sEVs

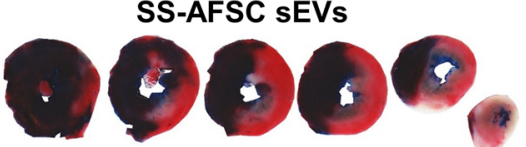

D $\mathrm{H}_{2} \mathrm{O}_{2}$ model:

SS-AFSC sEV effects

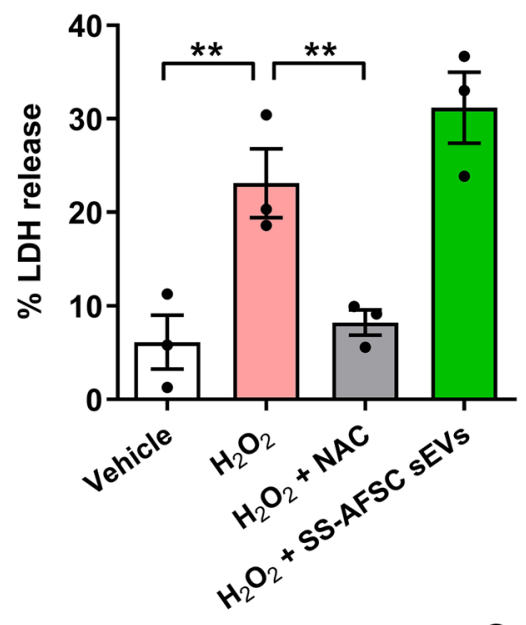

$F$

Hypoxia/reoxygenation model: SS-AFSC sEV effects

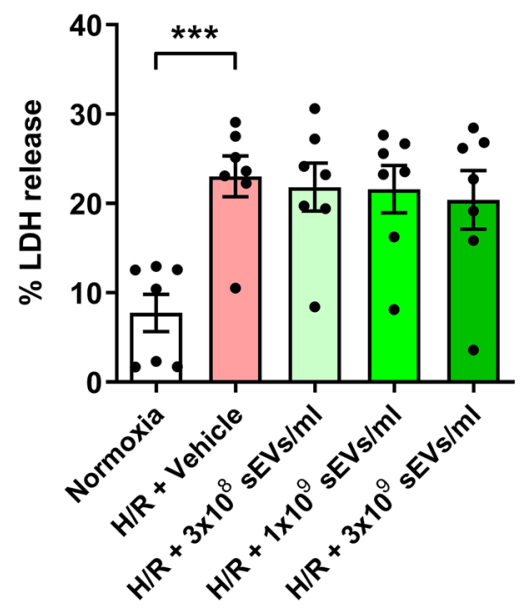

E

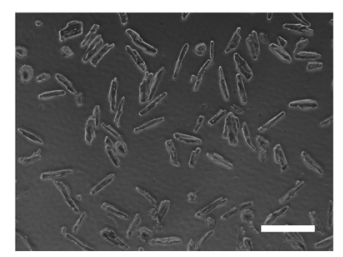

$\mathrm{H}_{2} \mathrm{O}_{2}+\mathrm{NAC}$

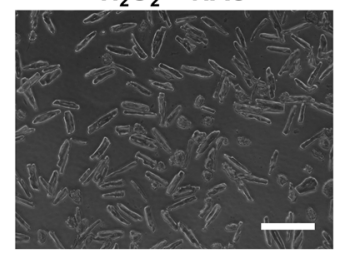

$\mathrm{H}_{2} \mathrm{O}_{2}+$ SS-AFSC sEVS

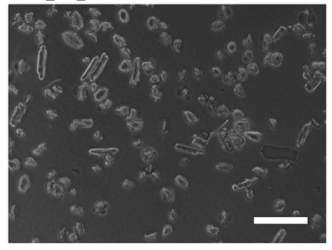

H

Hypoxia/reoxygenation model: HUVEC and SS-AFSC sEV effects

$H / R+$ Vehicle

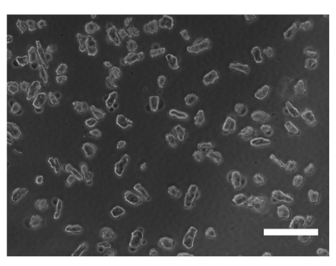

H/R + SS-AFSC sEVs $\left(3 \times 10^{\circ} / \mathrm{ml}\right)$

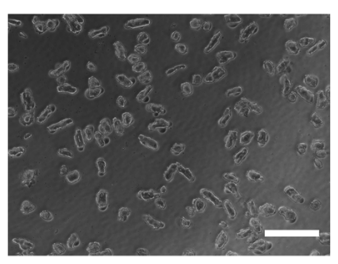


4Fig. 4 Effects of SS-hAFSC sEVs on cardioprotection in vivo and in vitro. a Infarct size as a percentage of the area at risk (ischaemic area) in a rat ischaemia-reperfusion injury model. Vehicle (PBS), Bradykinin $(40 \mu \mathrm{g} / \mathrm{kg})$, or SS-hAFSC sEVs $\left(2 \times 10^{11}\right.$ particles/rat $)$ were administered intravenously, 2 min prior to reperfusion. $n=6$. ${ }^{*} p<0.05$, one-way ANOVA with Dunnett's post hoc test. b Area at risk as a percentage of left ventricle area. $n=6 . p>0.05$, one-way ANOVA. c Representative images of a and b. d, e $\mathrm{H}_{2} \mathrm{O}_{2}$-induced death of primary cardiomyocytes treated with $40 \mu \mathrm{M} \mathrm{H}_{2} \mathrm{O}_{2}$ and Vehicle (water, PBS), $N$-acetyl-L-cysteine (NAC, $300 \mu \mathrm{M}$ ), or SS-hAFSC sEVs $\left(1 \times 10^{10}\right.$ particles $\left./ \mathrm{ml}\right)$. Cell death was assessed by LDH release. $* * p<0.01$, one-way repeated-measures ANOVA with Dunnett's post hoc test. $n=3$. Representative images are shown on e. Scale: $200 \mu \mathrm{m}$. f, g Hypoxia/reoxygenation-induced death of primary cardiomyocytes in the absence or presence of SS-hAFSC sEVs. Cell death was assessed by LDH release. ${ }^{* * *} p<0.001$, one-way repeated-measures ANOVA with Dunnett's post hoc test. $n=7$. Representative images are shown on g. Scale: $200 \mu \mathrm{M}$. h Effects of the stable sEV-treated HUVEC secretome in the hypoxia/reoxygenation-induced cardiomyocyte death model. Primary cardiomyocytes were treated with non-conditioned (Vehicle or sEVs at $1 \times 10^{10} \mathrm{sEVs} / \mathrm{ml}$ ) or HUVECconditioned medium (vehicle-treated: HUVEC + Vehicle, or sEVtreated: HUVEC $+\mathrm{sEVs}$ at $\left.1 \times 10^{10} \mathrm{sEVs} / \mathrm{ml}\right)$. *** $p<0.001$, $n s$ nonsignificant, one-way repeated-measures ANOVA with Tukey's post hoc test. $n=5$

AFSC sEVs to date and shows that they bear cardioprotective and marked promigratory abilities. These findings unveil the potential for foetal AFSC sEVs to be used as a new therapeutic in the setting of myocardial infarction.

The search for a perfect isolation technique to obtain completely pure sEVs from biological fluids or conditioned cell-culture medium continues. There is a considerable body of evidence that SEC may be among the best methods to purify vesicles from contaminants of a sample without compromising their integrity $[8,37,64]$. However, we $[55,56]$ and others $[53]$ have previously shown that SEC is highly prone to co-isolate soluble proteins and lipoproteins with sEVs from samples containing blood products such as serum. Hence, in this report, we used serum-free medium for SS-hAFSC culture to eliminate confounding contaminants and exploit the full potential of SEC to isolate sEVs with a better purity and improved functional efficacy [39]. Importantly, the SS-hAFSCs cultured under serum-free conditions showed only minor alterations in cell viability, morphology and expression of MSC markers, and longer, 48-h incubation timings yielded significantly more sEVs with a better purity than a 24-h incubation.

We demonstrate for the first time that SS-hAFSC sEVs can protect the animal heart from ischaemia-reperfusion injury when using a clinically suitable administration technique and injection timing (i.e., intravenous injection just prior to myocardial reperfusion). While the previous findings indicated that $\mathrm{sEVs}$ isolated from adult multipotent progenitors may have benefits in the setting of myocardial infarction, their clinical applicability is less clear because of ethical concerns (e.g., using embryonic stem cells to derive MSCs [34]) or difficulty of the process for obtaining the cells (e.g., differentiation of embryonic stem cells [34] and cardiac biopsies from diseased patients [7, 15]). Our findings are especially relevant in light of recent reports, demonstrating that sEVs from MSCs [45] or cardiosphere-derived cells [25] cannot exert cardioprotective benefits if delivered to the bloodstream. Since intravenous administration of MSCs or MSC-conditioned medium [59] is cardioprotective, it could be speculated that the intravenous cardioprotection of SShAFSC sEVs observed here may be due to their potent foetal nature. In support of the argument that SS-hAFSC sEVs are exceptionally potent, the dose of SEVs which we administered to rats in terms of protein content was $\sim 40-70 \mu \mathrm{g} / \mathrm{kg}$ and there is only one previous study of MSC sEVs which used a dose lower than this one [3].

In the current study, we investigated, for the first time, the effects of AFSC sEVs in a hypoxia/reoxygenation-induced primary cardiomyocyte death model. However, SS-hAFSC sEVs did not protect primary cardiomyocytes despite their potential to reduce infarct size in vivo. The lack of cytoprotective effects was also confirmed using a ROS-induced cell death model. Cardioprotection may also be mediated via an indirect mechanism, e.g., through effects on the endothelial cells [18]. Interestingly, no pro-survival effects of the secretome of HUVECs pretreated with SS-hAFSC sEVs were observed here. It should be noted that our model only assayed the stable cardioprotectant molecules released by the endothelial cells, and it is possible that released small, unstable molecules (e.g., nitric oxide) are responsible for the in vivo cardioprotection. It is also plausible that SShAFSC sEV protective activity is mediated via effects on other organs or cells (e.g., immune cells [15]).

There is some emerging evidence for a role of AFSC sEVs in angiogenesis, but it is not well defined mechanistically $[5,6]$. In fact, studies by Balbi et al. indicated that bulk AFSCs (not selected for SS-hAFSC) sEVs are not potent stimulators of angiogenesis [5, 6]. Our findings support the previous observations of Balbi et al. in vivo [5]. We have shown that SS-hAFSC sEVs promote migration of endothelial cells, but do not considerably affect their proliferation and tube formation. Intriguingly, medium conditioned by SS-hAFSCs was previously shown to promote migration, proliferation, and tube formation of endothelial colony forming cells derived from umbilical cord, but the most pronounced effects were seen in terms of promigratory activity [48].

Using two different approaches, it was demonstrated here that sEVs carry the chemotactic activity of SS-hAFSC-conditioned medium. Given that Balbi et al. argued that the 
presence of both soluble secretome and released $\mathrm{sEVs}$ is required to achieve efficient angiogenesis, it is possible that the $\mathrm{SEV}$ s are the active promigratory component of the SShAFSC-conditioned medium, while the soluble SS-hAFSC secretome may be required for the full angiogenic process (e.g., proliferation and tube formation). This is currently unknown and remains to be investigated.

The finding that SS-hAFSC sEVs are very efficient in promoting migration of endothelial cells but only modestly
Fig. 6 SS-hAFSC sEVs cargo. a, b Protein arrays for detection of angiogenic factors (a) and cytokines (b) in SS-hAFSC-conditioned medium and SS-hAFSC sEVs. Representative images of the membranes also shown. c Gene ontology (GO): Biological Process terms associated with cell migration and overrepresented in SS-hAFSC sEVs. Proteomic analysis of SS-hAFSC sEV-enriched proteins $(>1.5$ times) and SS-hAFSC sEV-exclusive proteins was performed. Red bars-expected number of proteins (based on the number of proteins in the human proteome); blue bars-observed number of proteins. See Supplementary Proteomics Table for full results
Fig. 5 Effects of SS-hAFSC $\mathrm{sEV}$ s on angiogenesis in vitro. a Using a modified Boyden's Chamber assay, HUVEC migration was assessed in response to vehicle (PBS), SS-hAFSC sEVs or $10 \%$ FBS (control). Migration is presented as mean staining intensity. ${ }^{*} p<0.05$, $* * p<0.01$, one-way repeatedmeasures ANOVA with Dunnett's post hoc test. $n=5$. Right panels-representative images (as indicated). Scale: $200 \mu \mathrm{m}$. b HUVEC proliferation was assessed using an MTT assay in the presence of vehicle (PBS) or SS-hAFSC sEVs. Proliferation is presented relative to a positive control of $10 \%$ FBS. ${ }^{*} p<0.05, * * p<0.01$, one-way repeated-measures ANOVA with Dunnett's post hoc test. $n=7$. c, $\mathbf{d}$ In vitro angiogenesis was assessed using an HUVEC tube formation assay in the absence of treatments (Control) or in the presence of VEGF $(25 \mathrm{ng} / \mathrm{ml})$, vehicle (PBS) or SS-hAFSC sEVs. Results are presented in $\mathbf{c}$ as number of tubes per field of analysis. $* * * p<0.001, n s$ non-significant, one-way repeated-measures ANOVA with Tukey's post hoc test. $n=3$. Representative images are shown in $\mathbf{d}$. Scale: $200 \mu \mathrm{m}$
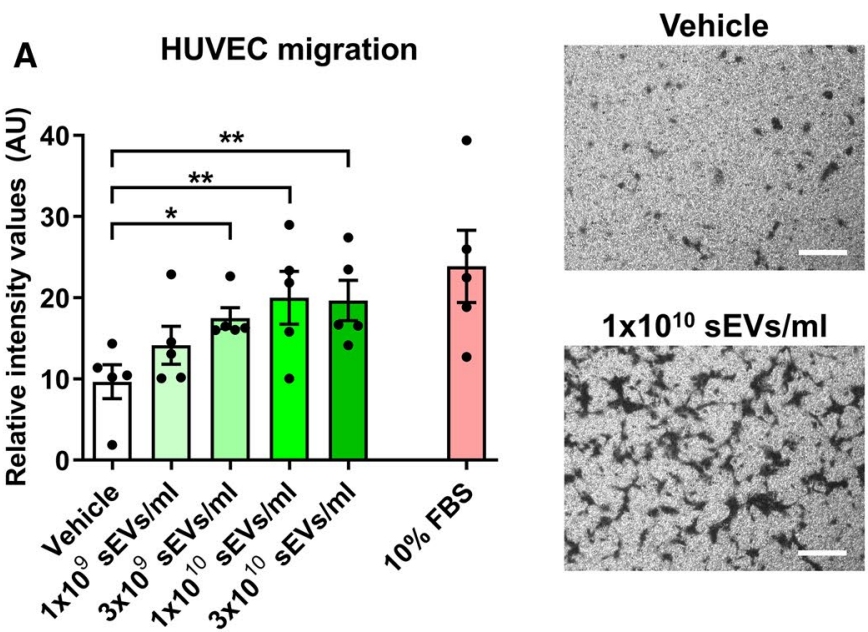

B

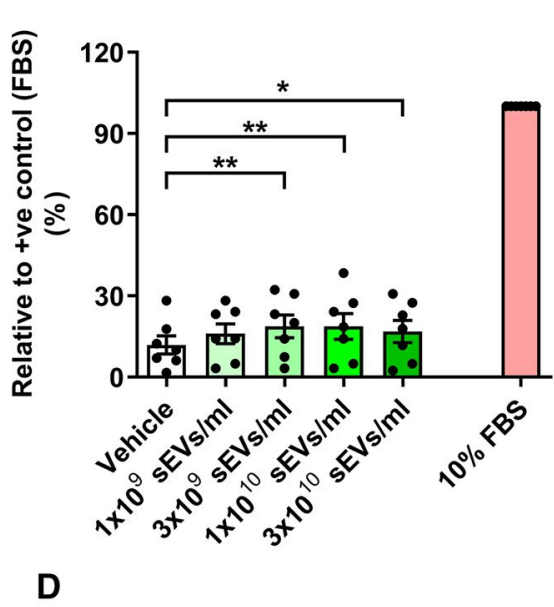

Control

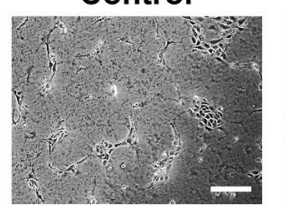

VEGF

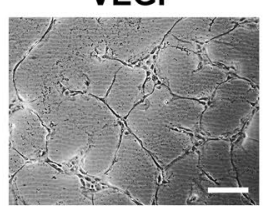

\section{HUVEC tube formation}


$3 \times 10^{9} \mathrm{sEVs} / \mathrm{ml}$

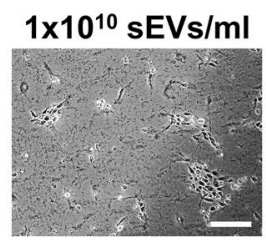

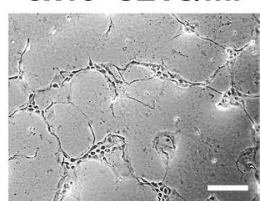

$3 \times 10^{10} \mathrm{sEVs} / \mathrm{ml}$

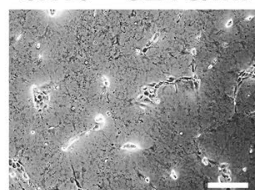




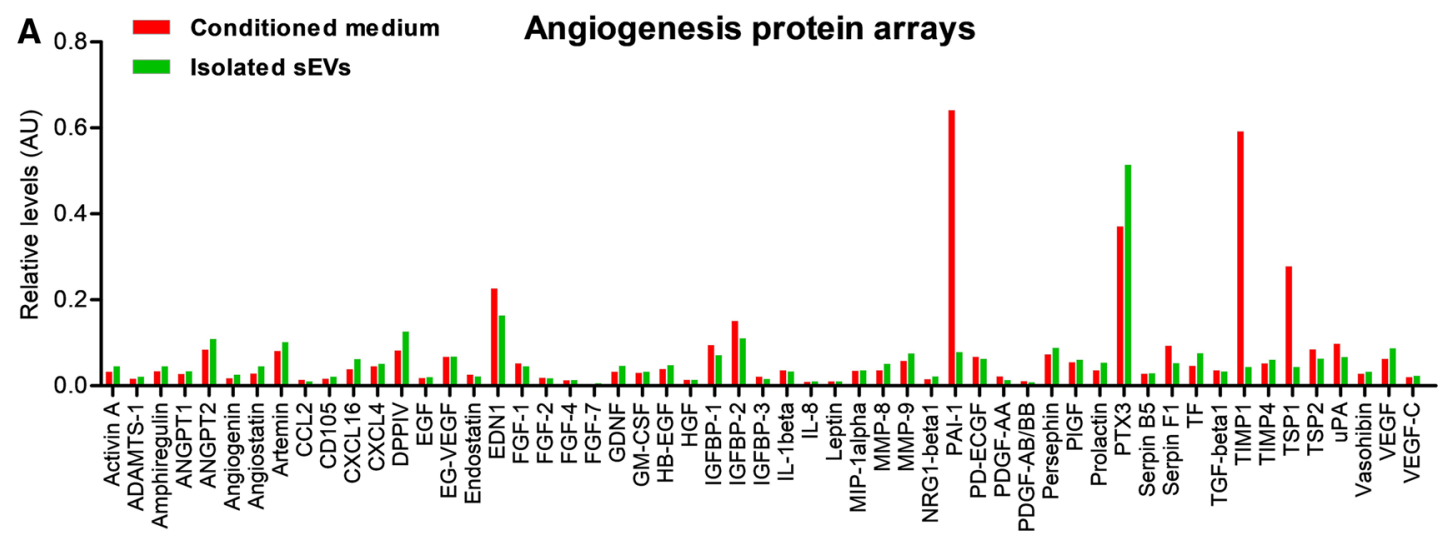

Conditioned medium

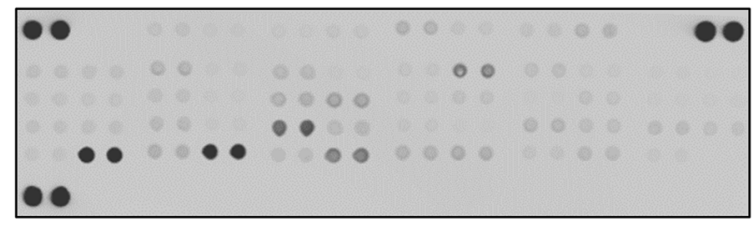

B
Isolated sEVs

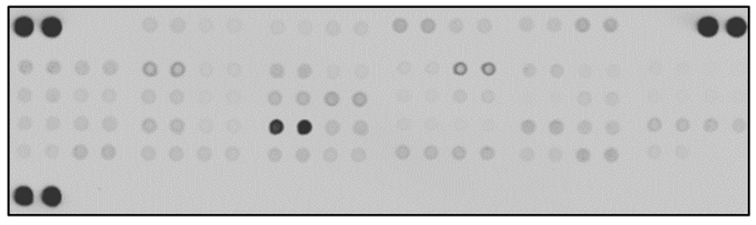



\section{Cytokine protein arrays}

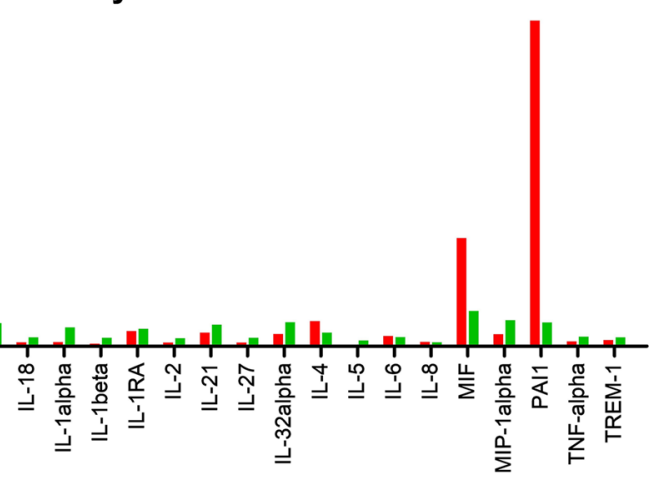

Isolated sEVs

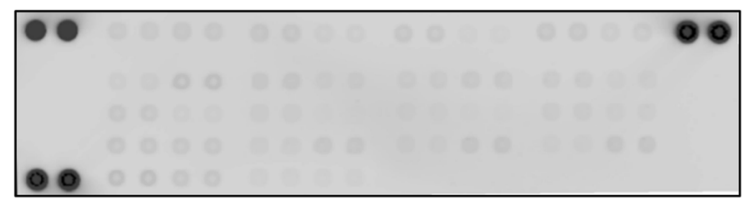

C

\section{positive regulation of locomotion}

positive regulation of cell adhesion

positive regulation of cell motility

positive regulation of cell migration

positive regulation of cytoskeleton organization positive regulation of actin filament bundle assembly

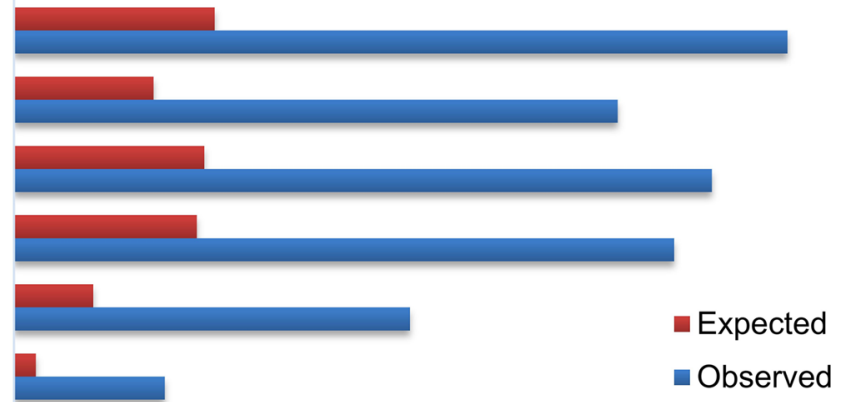

0

$5 \quad 10 \quad 15$

20

$25 \quad 30$

$35 \quad 40$ 
Fig. 7 Comparison of the promigratory effects of SShAFSC-conditioned medium and isolated SS-hAFSC sEVs and the mediators of these effects in the vesicular cargo. a HUVEC migration in response to SS-hAFSC-conditioned medium (CM) or isolated SShAFSC sEVs. $* * p<0.01$ vs Vehicle, ${ }^{* * *} p<0.001$ vs Vehicle, $\$ p<0.001$ vs CM (respective dose), one-way repeatedmeasures ANOVA with Tukey's post hoc test. $n=5$. b HUVEC migration in response to SShAFSC-conditioned medium (CM), SS-hAFSC-conditioned medium depleted of sEVs (CM-sEV-free) or isolated SS-hAFSC sEVs. $* * * p<0.001$, $n s$ non-significant, one-way repeated-measures ANOVA with Dunnett's post hoc test. $n=4$. $\mathbf{c}$ HUVEC migration in response to SS-hAFSC-conditioned medium $(\mathrm{CM})$ or SEC fractions of CM: sEVs (3-7 ml) or Protein (7-15 ml). sEVs and protein were normalised to the $\mathrm{CM}$ volume. $* p<0.05$, $* * * p<0.001$, one-way repeated-measures ANOVA with Tukey's post hoc test. $n=6$. d-h HUVEC migration in response to SS-hAFSC sEVs in combination with various inhibitors or antibodies: Anti-PTX3 antibody (d), $n=4$; AMD3100-CXCR4 inhibitor (e and f). $n=8$ (e). $n=5$ (f). TAK-242-TLR4 inhibitor (g). $n=4$. Anti-RTN4B antibody (h). $n=4 . * p<0.05, * * p<0.01$, $* * * p<0.001, n s$ non-significant $(p>0.05)$, one-way repeatedmeasures ANOVA with Tukey's post hoc test. Migration is presented as mean staining intensity in all panels

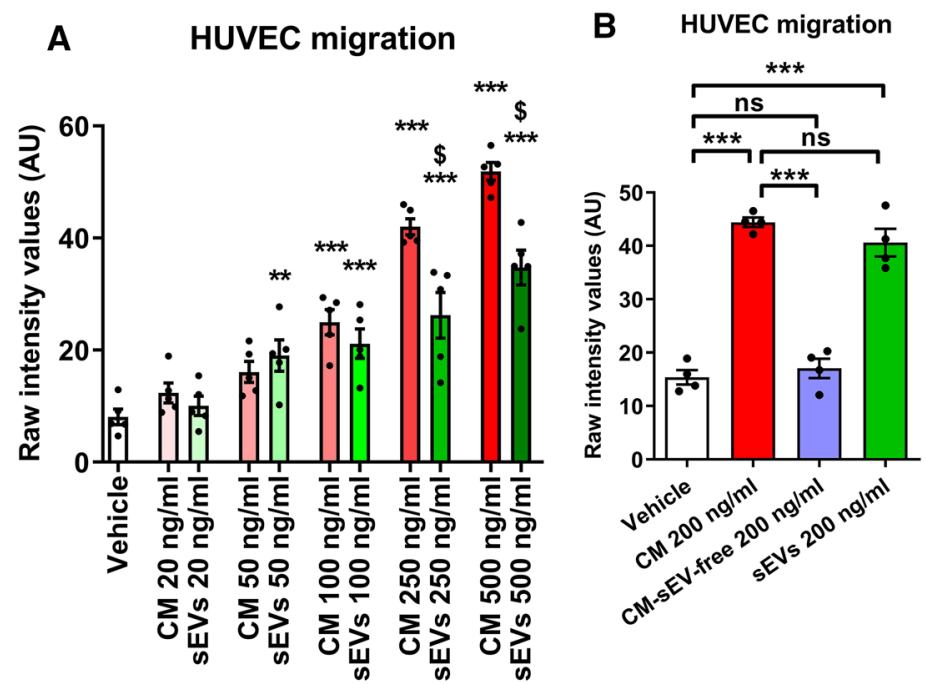

C HUVEC migration
D HUVEC migration

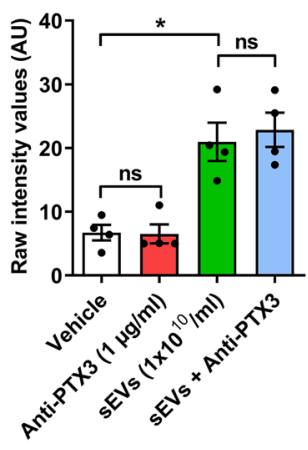

G HUVEC migration

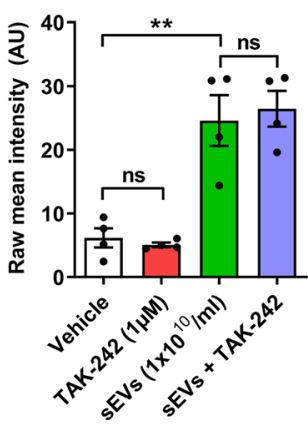

E HUVEC migration
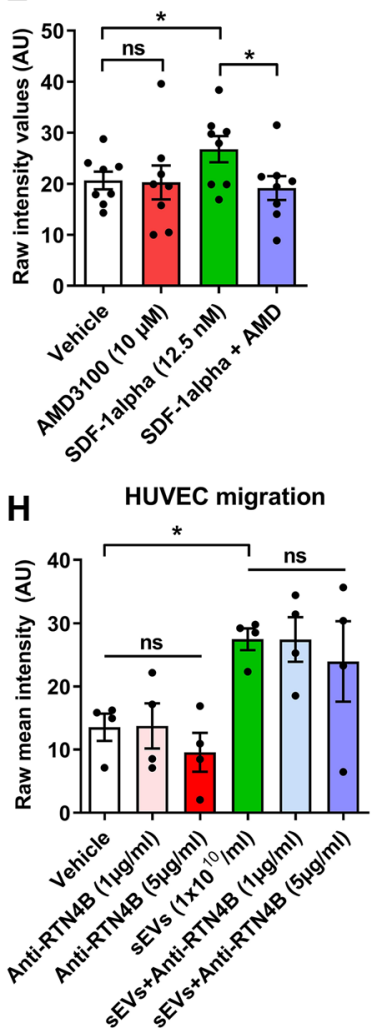

F HUVEC migration

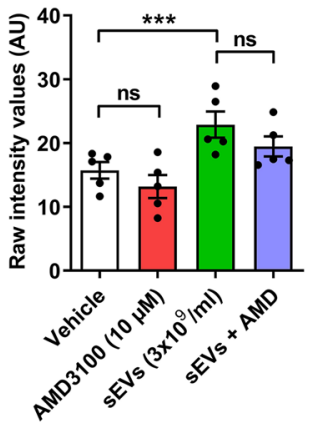

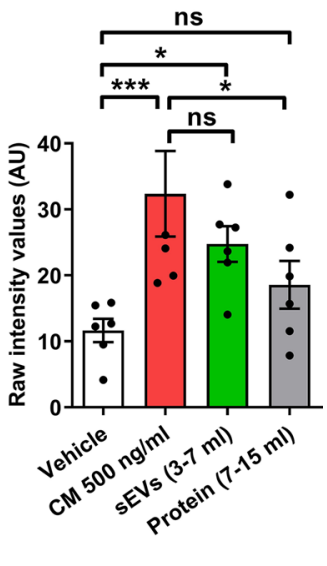

affect proliferation and do not stimulate tube formation is intriguing and quite unusual. It can be speculated that SShAFSC sEVs may only act on part of the angiogenic process. For instance, they may have promigratory but no mitogenic activity similar to other chemotactic factors [21].
Guided by data obtained using protein arrays and proteomics, we have attempted to determine the mediator of the promigratory effects of the SS-hAFSC sEVs. Among the identified putative promigratory proteins, SDF1 is a wellknown recruiting factor for endogenous progenitor cells [44, 
68] and it induces an angiogenic phenotype of endothelial progenitor cells [66]. Furthermore, SDF1 was previously shown to deliver endothelial-mediated cardioprotection [12] and to provide proangiogenic support to ischaemic hearts decreasing scars and increasing capillary density in vivo [50]. MIF, identified by our protein arrays, also induces chemotaxis via actions on CXCR4 receptor as shown using primary murine lymphocytes [31]. However, in the current study, pharmacological inhibition of CXCR4 did not affect SS-AFSC sEV-induced HUVEC migration, suggesting that vesicular SDF1 and MIF do not mediate this effect.

PTX3 was found to be relatively abundant in the sEV samples by both methods used here, and it showed an enrichment in the sEV isolates compared to the starting conditioned medium. Furthermore, PTX3 has previously been shown to induce the migration of pancreatic cancer cells [32]. However, inhibition of the PTX3 with the use of an antibody did not have an impact on the sEV-promoted endothelial cell migration.

Finally, the lack of effect of the selective TLR4 inhibitor TAK-242 on SS-hAFSC sEV-induced endothelial cell migration eliminated the possibility of TLR4 ligand-driven effects, such as BGN-induced migration [29], or contaminant endotoxin-driven migration [49]. Therefore, we were unable to identify a single protein involved in sEV-promoted endothelial cell migration. Notably, a multitargeted promigratory effect of the $\mathrm{sEVs}$ is also conceivable, since proteins associated with positive regulation of cell migration were part of different pathways as seen on our protein interaction network.

Despite our data-driven approach to select potential candidates for promigratory mediators, some of the most abundant proteins identified by LC-MS/MS were only a small fraction of the peptide area of the total proteins identified by label-free quantification. For instance, RTN4 was $<2 \%$ of the total peptide area despite being the ninth most abundant protein in the $\mathrm{sEV}$ isolates. Interestingly, type I collagens (COL1A1 and COL1A2) represented $>50 \%$ of the total peptide area detected indicative of a remarkably high abundance. It remains unknown whether these proteins contribute to HUVEC chemotaxis seen here, but it has been shown that collagen type I can induce morphological changes in endothelial cells and formation of capillary-like structures [65].

Importantly, it cannot be excluded that other SS-hAFSC sEV cargo such as microRNAs [60] or lipids [47] is responsible for their chemotactic effects, although these would have to act over a relatively short time-scale, since the assay only lasted $6 \mathrm{~h}$. It should also be noted that several arguments have been raised against the possibility of miRNAmediated effects of MSC sEVs, including the low miRNA concentration within EVs, low proportion of miRNA relative to other ribonucleic acid fragments, and the absence of RNA-induced silencing complex (RISC) proteins in the SEVs which are necessary for mature miRNA function [61].

Here, we demonstrated that PI3K signalling in endothelial cells is required for SS-hAFSC sEV-induced migration, although sEVs did not directly activate PI3K in HUVECs. This indicates that basal activity of PI3K pathway is necessary for the directional migration of HUVECs towards a gradient of SS-hAFSC sEVs and compromising the integrity of the endothelial PI3K can reduce the promigratory effects of sEVs. Further to that, administration of sEVs did not lead to an increase of phosphorylation in any of the kinases/kinase targets in the endothelial cells in the panel which we used, so it is likely that the sEVs act via other signalling pathways that have not been investigated here. These observations may be due to a more complex signalling owing to the multifaceted actions of the sEVs.

In conclusion, we established a method to isolate highly pure sEVs from medium conditioned by SS-hAFSCs. SShAFSC sEVs were cardioprotective and promigratory, and they were fully responsible for the chemotactic effects of the SS-hAFSC-conditioned medium. Overall, this report sheds light on the cardiovascular effects of sEVs obtained from young, foetal MSCs and may be a basis for future development of therapies for patients who have suffered a myocardial infarction. In future, it will also be interesting to assess the potential benefit of these SEVs in other disease indications affecting the heart including kidney disease [67]. 



D

४Fig. 8 Mechanism of SS-hAFSC sEV-induced endothelial cell migration. a Proteomic analysis of SS-hAFSC sEV-enriched proteins $(>1.5$ times) and SS-hAFSC sEV-exclusive proteins was performed. Overrepresented KEGG pathways are shown ranked by their $p$ values for enrichment. Red bars-expected number of proteins (based on the number of proteins in the human proteome); blue bars-observed number of proteins. b HUVEC migration in response to SS-hAFSC sEVs and vehicle (PBS, DMSO) or PI3K pathway inhibitor (GDC0941). $* * p<0.01, \quad * * * p<0.001, \quad n s$ non-significant $(p>0.05)$, one-way repeated-measures ANOVA with Tukey's post hoc test. $n=5$. c Western blotting results for total and phosphorylated AKT in endothelial cells. HUVECs were incubated with Vehicle (PBS, DMSO), GDC-0941, SS-hAFSC sEVs, SS-hAFSC sEVs + GDC0941 or insulin (control) for $15 \mathrm{~min}$. Results are presented relative to $500 \mathrm{nM}$ insulin control. ${ }^{* *} p<0.001$, one-way repeated-measures ANOVA with Tukey's post hoc test. $n=6$. Representative images shown on the right. p-AKT: phosphorylated AKT, t-AKT: total AKT. d Phospho-kinase array for detection of phosphorylated kinases/ kinase targets in endothelial cells. HUVECs were incubated with vehicle (PBS) or SS-hAFSC sEVs $\left(1 \times 10^{10}\right.$ particles/ml $)$ for $15 \mathrm{~min}$. Results are presented relative to control proteins. Images of the membranes shown in the top right corner: Vehicle (top, A053 and B053) and SS-hAFSC sEVs (bottom, A054 and B054)

Acknowledgements The authors would like to thank Mark Turmaine for his assistance with electron microscopy and Dr Filipa Vlahova for her advice on SS-hAFSC culture and characterisation.

Funding This work was supported by the British Heart Foundation [FS/15/70/32044 to K.T.] and the National Institute for Health Research Biomedical Research Centre [BRC233/CM/SD/101320 to S.D.].

\section{Compliance with ethical standards}

Conflict of interest The authors report no conflict of interest.

Open Access This article is licensed under a Creative Commons Attribution 4.0 International License, which permits use, sharing, adaptation, distribution and reproduction in any medium or format, as long as you give appropriate credit to the original author(s) and the source, provide a link to the Creative Commons licence, and indicate if changes were made. The images or other third party material in this article are included in the article's Creative Commons licence, unless indicated otherwise in a credit line to the material. If material is not included in the article's Creative Commons licence and your intended use is not permitted by statutory regulation or exceeds the permitted use, you will need to obtain permission directly from the copyright holder. To view a copy of this licence, visit http://creativecommons.org/licenses/by/4.0/.

\section{References}

1. Acevedo L, Yu J, Erdjument-Bromage H, Miao RQ, Kim JE, Fulton D, Tempst P, Strittmatter SM, Sessa WC (2004) A new role for Nogo as a regulator of vascular remodeling. Nat Med 10:382-388. https://doi.org/10.1038/nm1020

2. Amado LC, Saliaris AP, Schuleri KH, John MSt, Xie J-S, Cattaneo S, Durand DJ, Fitton T, Kuang JQ, Stewart G, Lehrke S, Baumgartner WW, Martin BJ, Heldman AW, Hare JM (2005) Cardiac repair with intramyocardial injection of allogeneic mesenchymal stem cells after myocardial infarction. Proc Natl Acad Sci 102:11474-11479. https://doi.org/10.1073/pnas.0504388102
3. Arslan F, Lai RC, Smeets MB, Akeroyd L, Choo A, Aguor ENE, Timmers L, van Rijen HV, Doevendans PA, Pasterkamp G, Lim SK, de Kleijn DP (2013) Mesenchymal stem cell-derived exosomes increase ATP levels, decrease oxidative stress and activate PI3K/Akt pathway to enhance myocardial viability and prevent adverse remodeling after myocardial ischemia/reperfusion injury. Stem Cell Res 10:301-312. https://doi.org/10.1016/j. scr.2013.01.002

4. Balbi C, Bollini S (2017) Fetal and perinatal stem cells in cardiac regeneration: moving forward to the paracrine era. Placenta 59:96-106

5. Balbi C, Lodder K, Costa A, Moimas S, Moccia F, van Herwaarden T, Rosti V, Campagnoli F, Palmeri A, De Biasio P, Santini F, Giacca M, Goumans M-J, Barile L, Smits AM, Bollini S (2019) Reactivating endogenous mechanisms of cardiac regeneration via paracrine boosting using the human amniotic fluid stem cell secretome. Int J Cardiol 287:87-95. https://doi.org/10.1016/j. ijcard.2019.04.011

6. Balbi C, Piccoli M, Barile L, Papait A, Armirotti A, Principi E, Reverberi D, Pascucci L, Becherini P, Varesio L, Mogni M, Coviello D, Bandiera T, Pozzobon M, Cancedda R, Bollini S (2017) First characterization of human amniotic fluid stem cell extracellular vesicles as a powerful paracrine tool endowed with regenerative potential. Stem Cells Transl Med 6:1-17. https://doi. org/10.1002/sctm.16-0297

7. Barile L, Lionetti V, Cervio E, Matteucci M, Gherghiceanu M, Popescu LM, Torre T, Siclari F, Moccetti T, Vassalli G (2014) Extracellular vesicles from human cardiac progenitor cells inhibit cardiomyocyte apoptosis and improve cardiac function after myocardial infarction. Cardiovasc Res 103:530-541. https://doi. org/10.1093/cvr/cvu167

8. Böing AN, van der Pol E, Grootemaat AE, Coumans FAW, Sturk A, Nieuwland R (2014) Single-step isolation of extracellular vesicles by size-exclusion chromatography. J Extracell Vesicles 3:1-11. https://doi.org/10.3402/jev.v3.23430

9. Bollini S, Cheung KK, Riegler J, Dong X, Smart N, Ghionzoli M, Loukogeorgakis SP, Maghsoudlou P, Dubé KN, Riley PR, Lythgoe MF, De Coppi P (2011) Amniotic fluid stem cells are cardioprotective following acute myocardial infarction. Stem Cells Dev 20:1985-1994. https://doi.org/10.1089/scd.2010.0424

10. Bøtker HE, Hausenloy D, Andreadou I, Antonucci S, Boengler K, Davidson SM, Deshwal S, Devaux Y, Di Lisa F, Di Sante M, Efentakis P, Femminò S, García-Dorado D, Giricz Z, Ibanez B, Iliodromitis E, Kaludercic N, Kleinbongard P, Neuhäuser M, Ovize M, Pagliaro P, Rahbek-Schmidt M, Ruiz-Meana M, Schlüter K-D, Schulz R, Skyschally A, Wilder C, Yellon DM, Ferdinandy P, Heusch G (2018) Practical guidelines for rigor and reproducibility in preclinical and clinical studies on cardioprotection. Basic Res Cardiol 113:39. https://doi.org/10.1007/s00395-018-0696-8

11. Boyden S (1962) The chemotactic effect of mixtures of antibody and antigen on polymorphonuclear leucocytes. J Exp Med 115:453-466. https://doi.org/10.1084/jem.115.3.453

12. Bromage DI, Taferner S, He Z, Ziff OJ, Yellon DM, Davidson SM (2019) Stromal cell-derived factor-1 $\alpha$ signals via the endothelium to protect the heart against ischaemia-reperfusion injury. $\mathrm{J}$ Mol Cell Cardiol 128:187-197. https://doi.org/10.1016/j.yjmcc .2019 .02 .002

13. Ceradini DJ, Kulkarni AR, Callaghan MJ, Tepper OM, Bastidas N, Kleinman ME, Capla JM, Galiano RD, Levine JP, Gurtner GC (2004) Progenitor cell trafficking is regulated by hypoxic gradients through HIF-1 induction of SDF-1. Nat Med 10:858-864. https:// doi.org/10.1038/nm1075

14. Corcelli M, Hawkins K, Vlahova F, Hunjan A, Dowding K, De Coppi P, David AL, Peebles D, Gressens P, Hagberg H, Hristova M, Guillot PV (2018) Neuroprotection of the hypoxic-ischemic mouse brain by human CD117+CD90+CD105+ amniotic fluid 
stem cells. Sci Rep 8:1-11. https://doi.org/10.1038/s41598-01820710-9

15. De Couto G, Gallet R, Cambier L, Jaghatspanyan E, Makkar N, Dawkins JF, Berman BP, Marbán E (2017) Exosomal MicroRNA Transfer Into Macrophages Mediates Cellular Postconditioning. Circulation 136:200-214. https://doi.org/10.1161/CIRCULATIO NAHA.116.024590

16. Davidson SM, Andreadou I, Barile L, Birnbaum Y, CabreraFuentes HA, Cohen MV, Downey JM, Girao H, Pagliaro P, Penna C, Pernow J, Preissner KT, Ferdinandy P (2019) Circulating blood cells and extracellular vesicles in acute cardioprotection. Cardiovasc Res 44:1156-1166. https://doi.org/10.1093/cvr/cvy314

17. Davidson SM, Ferdinandy P, Andreadou I, Bøtker HE, Heusch G, Ibáñez B, Ovize M, Schulz R, Yellon DM, Hausenloy DJ, Garcia-Dorado D (2019) Multitarget strategies to reduce myocardial ischemia/reperfusion injury. J Am Coll Cardiol 73:89-99. https ://doi.org/10.1016/j.jacc.2018.09.086

18. Davidson SM, Riquelme JA, Zheng Y, Vicencio JM, Lavandero S, Yellon DM (2018) Endothelial cells release cardioprotective exosomes that may contribute to ischaemic preconditioning. Sci Rep 8:1-9. https://doi.org/10.1038/s41598-018-34357-z

19. Davidson SM, Takov K, Yellon DM (2017) Exosomes and cardiovascular protection. Cardiovasc Drugs Ther 31:77-86. https:// doi.org/10.1007/s10557-016-6698-6

20. Davidson SM, Yellon DM (2018) Exosomes and cardioprotection-a critical analysis. Mol Aspects Med 60:104-114. https:// doi.org/10.1016/j.mam.2017.11.004

21. Davis S, Aldrich TH, Jones PF, Acheson A, Compton DL, Jain V, Ryan TE, Bruno J, Radziejewski C, Maisonpierre PC, Yancopoulos GD (1996) Isolation of angiopoietin-1, a ligand for the TIE2 receptor, by secretion-trap expression cloning. Cell 87:11611169. https://doi.org/10.1016/S0092-8674(00)81812-7

22. Van Deun J, Mestdagh P, Agostinis P, Akay Ö, Anand S, Anckaert J, Martinez ZA, Baetens T, Beghein E, Bertier L, Berx G, Boere J, Boukouris S, Bremer M, Buschmann D, Byrd JB, Casert C, Cheng L, Cmoch A, Daveloose D, De Smedt E, Demirsoy S, Depoorter V, Dhondt B, Driedonks TAP, Dudek A, Elsharawy A, Floris I, Foers AD, Gärtner K, Garg AD, Geeurickx E, Gettemans J, Ghazavi F, Giebel B, Kormelink TG, Hancock G, Helsmoortel H, Hill AF, Hyenne V, Kalra H, Kim D, Kowal J, Kraemer S, Leidinger P, Leonelli C, Liang Y, Lippens L, Liu S, Lo Cicero A, Martin S, Mathivanan S, Mathiyalagan P, Matusek T, Milani G, Monguió-Tortajada M, Mus LM, Muth DC, Németh A, Nolte-'t Hoen ENM, O'Driscoll L, Palmulli R, Pfaffl MW, Primdal-Bengtson B, Romano E, Rousseau Q, Sahoo S, Sampaio N, Samuel M, Scicluna B, Soen B, Steels A, Swinnen J V, Takatalo M, Thaminy S, Théry C, Tulkens J, Van Audenhove I, van der Grein S, Van Goethem A, van Herwijnen MJ, Van Niel G, Van Roy N, Van Vliet AR, Vandamme N, Vanhauwaert S, Vergauwen G, Verweij F, Wallaert A, Wauben M, Witwer KW, Zonneveld MI, De Wever O, Vandesompele J, Hendrix A, Hendrix A, EV-TRACK Consortium, Van Deun J, Mestdagh P, Agostinis P, Akay Ö, Anand S, Anckaert J, Martinez ZA, Baetens T, Beghein E, Bertier L, Berx G, Boere J, Boukouris S, Bremer M, Buschmann D, Byrd JB, Casert C, Cheng L, Cmoch A, Daveloose D, De Smedt E, Demirsoy S, Depoorter V, Dhondt B, Driedonks TAP, Dudek A, Elsharawy A, Floris I, Foers AD, Gärtner K, Garg AD, Geeurickx E, Gettemans J, Ghazavi F, Giebel B, Kormelink TG, Hancock G, Helsmoortel H, Hill AF, Hyenne V, Kalra H, Kim D, Kowal J, Kraemer S, Leidinger P, Leonelli C, Liang Y, Lippens L, Liu S, Lo Cicero A, Martin S, Mathivanan S, Mathiyalagan P, Matusek T, Milani G, Monguió-Tortajada M, Mus LM, Muth DC, Németh A, Nolte-'t Hoen ENM, O'Driscoll L, Palmulli R, Pfaffl MW, Primdal-Bengtson B, Romano E, Rousseau Q, Sahoo S, Sampaio N, Samuel M, Scicluna B, Soen B, Steels A, Swinnen J V, Takatalo M, Thaminy S, Théry C, Tulkens J, Van Audenhove I, van der Grein S, Van Goethem A, van Herwijnen MJ, Van Niel G, Van Roy N, Van Vliet AR, Vandamme N, Vanhauwaert S, Vergauwen G, Verweij F, Wallaert A, Wauben M, Witwer KW, Zonneveld MI, De Wever O, Vandesompele J, Hendrix A, Hendrix A 2017 EV-TRACK: transparent reporting and centralizing knowledge in extracellular vesicle research. Nat Methods 14: 228-232 Doi: 10.1038/nmeth.4185

23. Dominici M, Le Blanc K, Mueller I, Slaper-Cortenbach I, Marini F, Krause DS, Deans RJ, Keating A, Prockop DJ, Horwitz EM (2006) Minimal criteria for defining multipotent mesenchymal stromal cells. The international society for cellular therapy position statement. Cytotherapy 8:315-317. https://doi. org/10.1080/14653240600855905

24. Faulkner A, Purcell R, Hibbert A, Latham S, Thomson S, Hall WL, Wheeler-Jones C, Bishop-Bailey D (2014) A thin layer angiogenesis assay: a modified basement matrix assay for assessment of endothelial cell differentiation. BMC Cell Biol 15:41. https:// doi.org/10.1186/s12860-014-0041-5

25. Gallet R, Dawkins J, Valle J, Simsolo E, de Couto G, Middleton R, Tseliou E, Luthringer D, Kreke M, Smith RR, Marbán L, Ghaleh B, Marbán E (2017) Exosomes secreted by cardiosphere-derived cells reduce scarring, attenuate adverse remodelling, and improve function in acute and chronic porcine myocardial infarction. Eur Heart J 38:201-211

26. Gardiner C, Ferreira YJ, Dragovic RA, Redman CWG, Sargent IL (2013) Extracellular vesicle sizing and enumeration by nanoparticle tracking analysis. J Extracell vesicles $2: 1-11$. https://doi. org/10.3402/jev.v2i0.19671

27. Guillot PV, Gotherstrom C, Chan J, Kurata H, Fisk NM (2007) Human first-trimester fetal MSC express pluripotency markers and grow faster and have longer telomeres than adult MSC. Stem Cells 25:646-654. https://doi.org/10.1634/stemcells.2006-0208

28. Guillot PV, O'Donoghue K, Kurata H, Fisk NM (2006) Fetal stem cells: betwixt and between. Semin Reprod Med 24:340-347. https ://doi.org/10.1055/s-2006-952149

29. Hu L, Zang DM, Wang HX, Li JF, Su LP, Yan M, Li C, Yang QM, Liu BY, Zhu ZG (2016) Biglycan stimulates VEGF expression in endothelial cells by activating the TLR signaling pathway. Mol Oncol 10:1473-1484. https://doi.org/10.1016/j.molon c.2016.08.002

30. Kehl D, Generali M, Mallone A, Heller M, Uldry A-C, Cheng P, Gantenbein B, Hoerstrup SP, Weber B (2019) Proteomic analysis of human mesenchymal stromal cell secretomes: a systematic comparison of the angiogenic potential. npj Regen Med 4:8. https ://doi.org/10.1038/s41536-019-0070-y

31. Klasen C, Ohl K, Sternkopf M, Shachar I, Schmitz C, Heussen N, Hobeika E, Levit-Zerdoun E, Tenbrock K, Reth M, Bernhagen J, El Bounkari O (2014) MIF promotes B cell chemotaxis through the receptors CXCR4 and CD74 and ZAP-70 signaling. J Immunol 192:5273-5284. https://doi.org/10.4049/jimmunol.1302209

32. Kondo S, Ueno H, Hosoi H, Hashimoto J, Morizane C, Koizumi F, Tamura K, Okusaka T (2013) Clinical impact of pentraxin family expression on prognosis of pancreatic carcinoma. Br J Cancer 109:739-746. https://doi.org/10.1038/bjc.2013.348

33. Kowal J, Arras G, Colombo M, Jouve M, Morath JP, PrimdalBengtson B, Dingli F, Loew D, Tkach M, Théry C (2016) Proteomic comparison defines novel markers to characterize heterogeneous populations of extracellular vesicle subtypes. Proc Natl Acad Sci 113:E968-E977. https://doi.org/10.1073/pnas.15212 30113

34. Lai RC, Arslan F, Lee MM, Sze NSK, Choo A, Chen TS, SaltoTellez M, Timmers L, Lee CN, El Oakley RM, Pasterkamp G, de Kleijn DPV, Lim SK (2010) Exosome secreted by MSC reduces myocardial ischemia/reperfusion injury. Stem Cell Res 4:214222. https://doi.org/10.1016/j.scr.2009.12.003 
35. Linares R, Tan S, Gounou C, Arraud N, Brisson AR (2015) Highspeed centrifugation induces aggregation of extracellular vesicles. J Extracell Vesicles 4:29509. https://doi.org/10.3402/jev.v4.29509

36. Lindsey ML, Bolli R, Canty JM, Du X-J, Frangogiannis NG, Frantz S, Gourdie RG, Holmes JW, Jones SP, Kloner RA, Lefer DJ, Liao R, Murphy E, Ping P, Przyklenk K, Recchia FA, Schwartz Longacre L, Ripplinger CM, Van Eyk JE, Heusch G (2018) Guidelines for experimental models of myocardial ischemia and infarction. Am J Physiol Circ Physiol 314:H812H838. https://doi.org/10.1152/ajpheart.00335.2017

37. Lobb RJ, Becker M, Wen Wen S, Wong CSF, Wiegmans AP, Leimgruber A, Möller A (2015) Optimized exosome isolation protocol for cell culture supernatant and human plasma. J Extracell Vesicles 4:27031. https://doi.org/10.3402/jev.v4.27031

38. Mark P, Kleinsorge M, Gaebel R, Lux CA, Toelk A, Pittermann E, David R, Steinhoff G, Ma N (2013) Human mesenchymal stem cells display reduced expression of CD105 after culture in serum-free medium. Stem Cells Int 2013:698076. https://doi. org/10.1155/2013/698076

39. Mol EA, Goumans M-J, Doevendans PA, Sluijter JPG, Vader P (2017) Higher functionality of extracellular vesicles isolated using size-exclusion chromatography compared to ultracentrifugation. Nanomedicine 13:2061-2065. https://doi.org/10.1016/j. nano.2017.03.011

40. Moschidou D, Mukherjee S, Blundell MP, Drews K, Jones GN, Abdulrazzak H, Nowakowska B, Phoolchund A, Lay K, Ramasamy TS, Cananzi M, Nettersheim D, Sullivan M, Frost J, Moore G, Vermeesch JR, Fisk NM, Thrasher AJ, Atala A, Adjaye J, Schorle H, De Coppi P, Guillot PV (2012) Valproic acid confers functional pluripotency to human amniotic fluid stem cells in a transgene-free approach. Mol Ther 20:1953-1967. https://doi. org/10.1038/mt.2012.117

41. Mosmann T (1983) Rapid colorimetric assay for cellular growth and survival: application to proliferation and cytotoxicity assays. J Immunol Methods 65:55-63. https://doi.org/10.1016/00221759(83)90303-4

42. Van NG, Angelo GD, Raposo G, van Niel G, D’Angelo G, Raposo G (2018) Shedding light on the cell biology of extracellular vesicles. Nat Rev Mol Cell Biol 19:213-228. https://doi.org/10.1038/ nrm.2017.125

43. Osteikoetxea X, Sódar B, Németh A, Szabó-Taylor K, Pálóczi K, Vukman KV, Tamási V, Balogh A, Kittel Á, Pállinger É, Buzás EI (2015) Differential detergent sensitivity of extracellular vesicle subpopulations. Org Biomol Chem 13:9775-9782. https://doi. org/10.1039/C5OB01451D

44. Petit I, Jin D, Rafii S (2007) The SDF-1-CXCR4 signaling pathway: a molecular hub modulating neo-angiogenesis. Trends Immunol 28:299-307. https://doi.org/10.1016/j.it.2007.05.007

45. Potz BA, Scrimgeour LA, Pavlov VI, Sodha NR, Abid MR, Sellke FW (2018) Extracellular vesicle injection improves myocardial function and increases angiogenesis in a swine model of chronic ischemia. J Am Heart Assoc 7:e008344. https://doi.org/10.1161/ JAHA.117.008344

46. Raudvere U, Kolberg L, Kuzmin I, Arak T, Adler P, Peterson H, Vilo J (2019) g:Profiler: a web server for functional enrichment analysis and conversions of gene lists (2019 update). Nucleic Acids Res 47:1-8. https://doi.org/10.1093/nar/gkz369

47. Record M, Silvente-Poirot S, Poirot M, Wakelam MJO (2018) Extracellular vesicles: lipids as key components of their biogenesis and functions. J Lipid Res 59:1316-1324. https://doi. org/10.1194/JLR.E086173

48. Roubelakis MG, Tsaknakis G, Pappa KI, Anagnou NP, Watt SM (2013) Spindle shaped human mesenchymal stem/stromal cells from amniotic fluid promote neovascularization. PLoS ONE 8:e54747. https://doi.org/10.1371/journal.pone.0054747
49. Sarmiento D, Montorfano I, Cáceres M, Echeverría C, Fernández R, Cabello-Verrugio C, Cerda O, Tapia P, Simon F (2014) Endotoxin-induced vascular endothelial cell migration is dependent on TLR4/NF- $\mathrm{kB}$ pathway, $\mathrm{NAD}(\mathrm{P}) \mathrm{H}$ oxidase activation, and transient receptor potential melastatin 7 calcium channel activity. Int J Biochem Cell Biol 55:11-23. https://doi.org/10.1016/j.bioce 1.2014.08.001

50. Sasaki T, Fukazawa R, Ogawa S, Kanno S, Nitta T, Ochi M, Shimizu K (2007) Stromal cell-derived factor-1 $\alpha$ improves infarcted heart function through angiogenesis in mice. Pediatr Int 49:966-971. https://doi.org/10.1111/j.1442-200X.2007.02491.x

51. Siragusa M, Katare R, Meloni M, Damilano F, Hirsch E, Emanueli C, Madeddu P (2010) Involvement of phosphoinositide 3-kinase gamma in angiogenesis and healing of experimental myocardial infarction in mice. Circ Res 106:757-768. https://doi.org/10.1161/ CIRCRESAHA.109.207449

52. Sluijter JPG, Davidson SM, Boulanger CM, Buzás EI, de Kleijn DPV, Engel FB, Giricz Z, Hausenloy DJ, Kishore R, Lecour S, Leor J, Madonna R, Perrino C, Prunier F, Sahoo S, Schiffelers RM, Schulz R, Van Laake LW, Ytrehus K, Ferdinandy P (2018) Extracellular vesicles in diagnostics and therapy of the ischaemic heart: position paper from the working group on cellular biology of the heart of the European society of cardiology. Cardiovasc Res 114:19-34. https://doi.org/10.1093/cvr/cvx211

53. Sódar BW, Kittel Á, Pálóczi K, Vukman KV, Osteikoetxea X, Szabó-Taylor K, Németh A, Sperlágh B, Baranyai T, Giricz Z, Wiener Z, Turiák L, Drahos L, Pállinger É, Vékey K, Ferdinandy P, Falus A, Buzás EI (2016) Low-density lipoprotein mimics blood plasma-derived exosomes and microvesicles during isolation and detection. Sci Rep 6:24316. https://doi.org/10.1038/srep2 4316

54. Szklarczyk D, Gable AL, Lyon D, Junge A, Wyder S, HuertaCepas J, Simonovic M, Doncheva NT, Morris JH, Bork P, Jensen LJ, von Mering C (2019) STRING v11: protein-protein association networks with increased coverage, supporting functional discovery in genome-wide experimental datasets. Nucleic Acids Res 47:D607-D613. https://doi.org/10.1093/nar/gky1131

55. Takov K, Yellon DM, Davidson SM (2017) Confounding factors in vesicle uptake studies using fluorescent lipophilic membrane dyes. J Extracell Vesicles 6:1388731. https://doi.org/10.1080/20013 078.2017.1388731

56. Takov K, Yellon DM, Davidson SM (2019) Comparison of small extracellular vesicles isolated from plasma by ultracentrifugation or size-exclusion chromatography: yield, purity and functional potential. J Extracell Vesicles 8:1560809. https://doi. org/10.1080/20013078.2018.1560809

57. Théry C, Amigorena S, Raposo G, Clayton A (2006) Isolation and characterization of exosomes from cell culture supernatants and biological fluids. Curr Protoc cell Biol 30:3.22.1-3.22.29

58. Théry C, Witwer KW, Aikawa E, Alcaraz MJ, Anderson JD, Andriantsitohaina R, Antoniou A, Arab T, Archer F, Atkin-Smith GK, Ayre DC, Bach J-M, Bachurski D, Baharvand H, Balaj L, Baldacchino S, Bauer NN, Baxter AA, Bebawy M, Beckham C, Bedina Zavec A, Benmoussa A, Berardi AC, Bergese P, Bielska E, Blenkiron C, Bobis-Wozowicz S, Boilard E, Boireau W, Bongiovanni $\mathrm{A}$, Borràs $\mathrm{FE}$, Bosch $\mathrm{S}$, Boulanger $\mathrm{CM}$, Breakefield $\mathrm{X}$, Breglio AM, Brennan MÁ, Brigstock DR, Brisson A, Broekman ML, Bromberg JF, Bryl-Górecka P, Buch S, Buck AH, Burger D, Busatto S, Buschmann D, Bussolati B, Buzás EI, Byrd JB, Camussi G, Carter DR, Caruso S, Chamley LW, Chang Y, Chen C, Chen S, Cheng L, Chin AR, Clayton A, Clerici SP, Cocks A, Cocucci E, Coffey RJ, Cordeiro-da-Silva A, Couch Y, Coumans FA, Coyle B, Crescitelli R, Criado MF, D'Souza-Schorey C, Das S, Datta Chaudhuri A, de Candia P, De Santana EF, De Wever O, del Portillo HA, Demaret T, Deville S, Devitt A, Dhondt B, Di Vizio D, Dieterich LC, Dolo V, Dominguez Rubio AP, 
Dominici M, Dourado MR, Driedonks TA, Duarte F V, Duncan HM, Eichenberger RM, Ekström K, EL Andaloussi S, Elie-Caille C, Erdbrügger U, Falcón-Pérez JM, Fatima F, Fish JE, FloresBellver M, Försönits A, Frelet-Barrand A, Fricke F, Fuhrmann G, Gabrielsson S, Gámez-Valero A, Gardiner C, Gärtner K, Gaudin R, Gho YS, Giebel B, Gilbert C, Gimona M, Giusti I, Goberdhan DC, Görgens A, Gorski SM, Greening DW, Gross JC, Gualerzi A, Gupta GN, Gustafson D, Handberg A, Haraszti RA, Harrison P, Hegyesi H, Hendrix A, Hill AF, Hochberg FH, Hoffmann KF, Holder B, Holthofer H, Hosseinkhani B, Hu G, Huang Y, Huber V, Hunt S, Ibrahim AG, Ikezu T, Inal JM, Isin M, Ivanova A, Jackson HK, Jacobsen S, Jay SM, Jayachandran M, Jenster G, Jiang L, Johnson SM, Jones JC, Jong A, Jovanovic-Talisman T, Jung S, Kalluri R, Kano S, Kaur S, Kawamura Y, Keller ET, Khamari D, Khomyakova E, Khvorova A, Kierulf P, Kim KP, Kislinger T, Klingeborn M, Klinke DJ, Kornek M, Kosanović MM, Kovács ÁF, Krämer-Albers E-M, Krasemann S, Krause M, Kurochkin I V, Kusuma GD, Kuypers S, Laitinen S, Langevin SM, Languino LR, Lannigan J, Lässer C, Laurent LC, Lavieu G, Lázaro-Ibáñez E, Le Lay S, Lee M-S, Lee YXF, Lemos DS, Lenassi M, Leszczynska A, Li IT, Liao K, Libregts SF, Ligeti E, Lim R, Lim SK, Linē A, Linnemannstöns K, Llorente A, Lombard CA, Lorenowicz MJ, Lörincz ÁM, Lötvall J, Lovett J, Lowry MC, Loyer X, Lu Q, Lukomska B, Lunavat TR, Maas SL, Malhi H, Marcilla A, Mariani J, Mariscal J, Martens-Uzunova ES, Martin-Jaular L, Martinez MC, Martins VR, Mathieu M, Mathivanan S, Maugeri M, McGinnis LK, McVey MJ, Meckes DG, Meehan KL, Mertens I, Minciacchi VR, Möller A, Møller Jørgensen M, Morales-Kastresana A, Morhayim J, Mullier F, Muraca M, Musante L, Mussack V, Muth DC, Myburgh KH, Najrana T, Nawaz M, Nazarenko I, Nejsum P, Neri C, Neri T, Nieuwland R, Nimrichter L, Nolan JP, Nolte-'t Hoen EN, Noren Hooten N, O'Driscoll L, O'Grady T, O'Loghlen A, Ochiya T, Olivier M, Ortiz A, Ortiz LA, Osteikoetxea X, Østergaard O, Ostrowski M, Park J, Pegtel DM, Peinado H, Perut F, Pfaffl MW, Phinney DG, Pieters BC, Pink RC, Pisetsky DS, Pogge von Strandmann E, Polakovicova I, Poon IK, Powell BH, Prada I, Pulliam L, Quesenberry P, Radeghieri A, Raffai RL, Raimondo S, Rak J, Ramirez MI, Raposo G, Rayyan MS, Regev-Rudzki N, Ricklefs FL, Robbins PD, Roberts DD, Rodrigues SC, Rohde E, Rome S, Rouschop KM, Rughetti A, Russell AE, Saá P, Sahoo S, Salas-Huenuleo E, Sánchez C, Saugstad JA, Saul MJ, Schiffelers RM, Schneider R, Schøyen TH, Scott A, Shahaj E, Sharma S, Shatnyeva O, Shekari F, Shelke GV, Shetty AK, Shiba K, Siljander PR-M, Silva AM, Skowronek A, Snyder OL, Soares RP, Sódar BW, Soekmadji C, Sotillo J, Stahl PD, Stoorvogel W, Stott SL, Strasser EF, Swift S, Tahara H, Tewari M, Timms K, Tiwari S, Tixeira R, Tkach M, Toh WS, Tomasini R, Torrecilhas AC, Tosar JP, Toxavidis V, Urbanelli L, Vader P, van Balkom BW, van der Grein SG, Van Deun J, van Herwijnen MJ, Van KeurenJensen K, van Niel G, van Royen ME, van Wijnen AJ, Vasconcelos MH, Vechetti IJ, Veit TD, Vella LJ, Velot É, Verweij FJ,
Vestad B, Viñas JL, Visnovitz T, Vukman K V, Wahlgren J, Watson DC, Wauben MH, Weaver A, Webber JP, Weber V, Wehman AM, Weiss DJ, Welsh JA, Wendt S, Wheelock AM, Wiener Z, Witte L, Wolfram J, Xagorari A, Xander P, Xu J, Yan X, YáñezMó M, Yin H, Yuana Y, Zappulli V, Zarubova J, Žèkas V, Zhang J, Zhao Z, Zheng L, Zheutlin AR, Zickler AM, Zimmermann P, Zivkovic AM, Zocco D, Zuba-Surma EK (2018) Minimal information for studies of extracellular vesicles 2018 (MISEV2018): a position statement of the international society for extracellular vesicles and update of the MISEV2014 guidelines. J Extracell Vesicles 7:1535750. Doi: 10.1080/20013078.2018.1535750

59. Timmers L, Lim SK, Arslan F, Armstrong JS, Hoefer IE, Doevendans PA, Piek JJ, El Oakley RM, Choo A, Lee CN, Pasterkamp G, de Kleijn DPV (2008) Reduction of myocardial infarct size by human mesenchymal stem cell conditioned medium. Stem Cell Res 1:129-137. https://doi.org/10.1016/j.scr.2008.02.002

60. Todorova D, Simoncini S, Lacroix R, Sabatier F, Dignat-George F (2017) Extracellular vesicles in angiogenesis. Circ Res 120:16581673. https://doi.org/10.1161/CIRCRESAHA.117.309681

61. Toh WS, Lai RC, Zhang B, Lim SK (2018) MSC exosome works through a protein-based mechanism of action. Biochem Soc Trans 46:843-853. https://doi.org/10.1042/BST20180079

62. Vlahova F, Hawkins KE, Ranzoni AM, Hau K-L, Sagar R, De Coppi P, David AL, Adjaye J, Guillot PV (2019) Human midtrimester amniotic fluid (stem) cells lack expression of the pluripotency marker OCT4A. Sci Rep 9:8126. https://doi.org/10.1038/ s41598-019-44572-x

63. Webber J, Clayton A (2013) How pure are your vesicles? J Extracell Vesicles 2:1-6. https://doi.org/10.3402/jev.v2i0.19861

64. Welton JL, Webber JP, Botos L, Jones M, Clayton A (2015) Ready-made chromatography columns for extracellular vesicle isolation from plasma. J Extracell Vesicles 4:27269. https://doi. org/10.3402/jev.v4.27269

65. Whelan MC, Senger DR (2003) Collagen I initiates endothelial cell morphogenesis by inducing actin polymerization through suppression of cyclic AMP and protein kinase A. J Biol Chem 278:327-334. https://doi.org/10.1074/jbc.M207554200

66. Zemani F, Silvestre J-SSJ-SJ-S, Fauvel-Lafeve F, Bruel A, Vilar J, Bieche I, Laurendeau I, Galy-Fauroux I, Fischer AM, BoissonVidal C (2008) Ex vivo priming of endothelial progenitor cells with SDF-1 before transplantation could increase their proangiogenic potential. Arterioscler Thromb Vasc Biol 28:644-650. https ://doi.org/10.1161/ATVBAHA.107.160044

67. Zhang L, Zhu XY, Zhao Y, Eirin A, Liu L, Ferguson CM, Tang H, Lerman A, Lerman LO (2020) Selective intrarenal delivery of mesenchymal stem cell-derived extracellular vesicles attenuates myocardial injury in experimental metabolic renovascular disease. Basic Res Cardiol 115:16. https://doi.org/10.1007/s0039 5-019-0772-8

68. Ziff OJ, Bromage DI, Yellon DM, Davidson SM (2018) Therapeutic strategies utilizing SDF-1 $\alpha$ in ischaemic cardiomyopathy. Cardiovasc Res 114:358-367. https://doi.org/10.1093/cvr/cvx203 